\title{
Candidate Genes in Hypertension
}

\author{
Hayet Soualmia \\ High Institut of Medical Technologies of Tunis, \\ Biochemistry Laboratory LR99ES11, Rabta University Hospital, Tunis, \\ Tunisia
}

\section{Introduction}

Essential hypertension $(\mathrm{EH})$ is a polygenic and multifactorial disorder that results from genetic and/or environmental factors (Lifton et al., 2001). This disease has no identifiable origin, but results from a disturbance of systems regulating blood pressure (BP) such as several circulating and local neurohumoral and vasoactive factors. Genetic variations of these factors could play a role in the genesis of $\mathrm{EH}$ which represents a major risk factor for ischemic heart disease, stroke, peripheral vascular disease and progressive renal damage (Mesrati, 2007). EH rises with age, and it aggregates with other cardiovascular risk factors, such as dyslipidaemia, glucose intolerance, hyperinsulinaemia, abdominal obesity, and hyperuricaemia. Other environmental factors influence this disease like high dietary intake of sodium, alcohol, and stress. Family history, appears to play a major role because EH is more likely to develop in individuals when there is a strong family history. Several studies have identified a variety of candidate genes in $\mathrm{EH}$ as well as their interaction with one another and with the environment. Among these hypertension-predisposition genes investigated, genes involved in the renin-angiotensin-aldosterone system, catecholaminergic/adrenergic function, genes of signal transduction system as $G$ protein $\beta 3$ subunit, sodium channel system, a adducin and atrial natriuretic peptides. Several other biomarkers have been reported to increase the ability to predict $\mathrm{EH}$ such as hormone receptors like glucagon receptor and insulin like growth factor 1 (O'Shaughnessy, 2001, Timberlake et al., 2001) and other systems as endothelin, apolipoprotein and cytokine systems. In this chapter, we expose the genetic markers of $\mathrm{EH}$ and their expression related to lifestyle through several strategies such as investigation of specific candidate genes, genome-wide searches, use of intermediate phenotypes, comparative genomics and a combination of these methods (Timberlake et al., 2001)

\section{Candidate genes in hypertension}

A large number of candidate genes previously known and novel candidate genes that mediate susceptibility to hypertension are identified. The notion that hypertension is a polygenic disease, is reinforced by advanced biotechnological tools, and data are provided as to the actual number of genes involved, gene-gene interaction or gene-environmentinteraction. The renin-angiotensin-aldosterone system is widely implicated and other gene systems are also emerging. 


\subsection{The renin-angiotensin-aldosterone system}

The renin-angiotensin-aldosteron system (RAAS) is implicated in the control of BP and sodium balance. This system plays a key role in the regulation of kidney function. Genetic variations of components of the RAAS such as the renin (REN), angiotensinogen (AGT), angiotensin II-type 1 receptor (AGTR1), angiotensin-converting enzyme (ACE) (Allikmets et al., 1999) and aldosterone (CYP11B2) genes have been shown to be associated with susceptibility to EH.

\subsubsection{Renin}

Renin is the catalytic enzyme acting on angiotensinogen. It is encoded by the renin (REN) gene located at the 1q32 region. Several studies prove that the REN gene increases BP and susceptibility to hypertension. REN gene insertion/deletion (I/D) polymorphism is found to be associated with EH (Ying et al., 2010) and multiple REN SNPs are significantly associated with risk for hypertension. In the single SNP analysis, the strongest association with hypertension was seen with rs6693954, which is in high linkage disequilibrium with rs2368564 located at intron 9 (Sun et al., 2001). The REN-5312T allele has been reported to be associated with elevated diastolic BP (Vangjeli et al., 2010). Furthermore, the Bgl I variant in intron 1 and the 10501G/A SNP in exon 9 were associated with hypertension in US white and Gulf Arabs group from the United Arab Emirates (Frossard et al., 2001, Ahmad et al., 2005). In addition, an association of C-4021T and C-3212T with hypertension has been identified in African Americans (Zhu et al., 2003) and a SNP in intron 4 (54620025A/C) was shown to be associated with elevated BP and hypertension in Spanish women (Mansego et al., 2008). All these studies provide evidence that renin is an important candidate gene for $\mathrm{EH}$.

\subsubsection{Angiotensinogen}

Angiotensinogen (AGT) gene located on chromosome 1q42-43, contains five exons spanning $13 \mathrm{~kb}$ (Gaillard et al., 1989). AGT is cleaved by renin to the decapeptide angiotensin (Ang) I precursor of Ang II. Significant evidence supporting the genetic susceptibility of the AGT locus for hypertension has been provided by many studies in various ethnic groups. A number of associated single nucleotide polymorphisms (SNPs) has been identified including M235T (rs669), T174M (rs4762), and G-217A (rs5049). Several studies have reported that the $235 \mathrm{~T}$ and T174 allele increased the risk of EH (Jeunmaitre, 2008, Kunz et al., 1997, Fang et al., 2010, Sethi et al., 2003). Moreover, mutation in the promoter region that involves the presence of an adenine (A) instead of a guanine (G) 6 bp upstream from the transcription initiation site (G-6A) has been reported to have a positive correlation with hypertension (Wang et al., 2002). This mutation has been identified in a Taiwanese aboriginals, where the prevalence of the $-6 \mathrm{~A}$ and $235 \mathrm{~T}$ variants of the AGT gene are high and are significantly associated with hypertension (Wang et al., 2002). Among all these AGT polymorphisms gene, the M268T variant is the most studied in several populations and representes a candidate gene for EH (Gopi-Chand et al., 2011).

\subsubsection{Angiotensin-converting-enzyme}

The angiotensin-converting-enzyme (ACE) is located on chromosome 17q23. In addition to increasing the production of Ang II, it is also responsible for the degradation of bradikinin, a 
vasodilating and natriuretic substance. Several polymorphisms were present in the ACE gene but the prominent of these polymorphisms is the insertion or deletion (I/D) of $287 \mathrm{pb}$ in intron 16 of this gene. Previous studies have reported that this polymorphism affected both serum ACE concentration and BP (Rigat et al., 1990), and DD genotype carriers have twice as high as ACE concentration compared to II genotype carriers, while subjects with ID genotype has intermediate or moderate ACE plasma concentration. In several studies, the D allele showed statistically significant relationship with hypertension in different populations. Thus, the ACE gene is a candidate gene for EH in humans.

\subsubsection{Angiotensin II type 1 receptor}

The human gene for angiotensin II type 1 receptor (AGTR1) located at chromosome 3q21-25, has a length of $>55 \mathrm{~kb}$, is composed of five exons and four introns. A single nucleotide polymorphism (SNP) has been described in which there is either an adenine (A) or a cytosine $(\mathrm{C})$ base $(\mathrm{A} / \mathrm{C})$ transversion in position 1166 in the $3^{\prime}$ untranslated region of the gene (Bonnardeaux et al., 1994). The $+1166 \mathrm{~A} / \mathrm{C}$ polymorphism is the most studied and evaluated. Nine other SNPs influencing AGTR1 expression were described (Erdmann et al., 1999) and seven other SNPs reported in the $5^{\prime}$ flanking region of the gene, were not in linkage equilibrium with +1166 A $/ C$ polymorphism (Poirier et al., 1998, Takahashi et al., 2000). Moreover, the SNP at nucleotide position +573 was investigated in hypertension and diabetes (Doria et al., 1997, Chaves et al., 2001) and several other new SNPs have been described, however, not all of them are associated with hypertension. In some studies, a linkage disequilibrium was shown betweeen these new SNPs and the +1166 A/C polymorphism, in particular the $-153 \mathrm{~A} / \mathrm{G}$ polymorphism (Lajemi et al., 2001). In addition, the +1166 A/C variant in the AGTR1 gene was associated with the severe form of EH (Bonnardeaux et al., 1994; Kainulainen et al., 1999) and in Caucasian hypertensive subjects with a strong family history, the C allele was over-represented (Wang et al., 1997) and more frequent in women with pregnancy induced hypertension. Several other studies have reported significant interaction between the AGTR1 +1166A/C polymorphism and hypertension in different populations (Wang \&Staessen, 2000, Henskens et al., 2003). So, the $1166 \mathrm{~A} / \mathrm{C}$ polymorphism in the AGTR1 gene is a biomarker for $\mathrm{EH}$.

\subsubsection{Angiotensin II type 2 receptor}

The angiotensin II type-2 receptor (AGTR2) gene is located on the X-chromosome. It consists of 3 exons and 2 introns, with the entire open reading frame of the AGTR2 located on exon 3 (Martin \& Elton 1995). The AGTR2 is thought to oppose the growth promoting effect of the AGTR1 and was the mediator for vasodilatation, natriuresis and apoptosis of smooth muscle cells. A commonly occurring intronic polymorphism has been described at a lariat branch-point in intron 1 (Nishimura et al. 1999). Its position, described relative to the translation initiation site of the human AGTR2 gene, is $(-1332 \mathrm{~A} / \mathrm{G})$ (Nishimura et al. 1999), although it has also been previously described by others (Erdmann et al., 2000) as $(+1675)$. It is located 29 bp before exon 2, close to the region that is important for transcriptional activity (Warnecke et al. 1999). The AGTR2 A1675G polymorphism was shown to be involved in the development of EH in male (Zivkovic et al., 2007, Delles et al. 2000, Jin et al., 2003a, Alfakih et al., 2004), whereas the G4599A polymorphism located in exon 3 of the AGTR2 gene was associated with hypertension in women. Other SNPs in the 
AGTR2 gene were identified by Zhang et al. (2003) suggesting a relationship between the $1334 \mathrm{~T} / \mathrm{C}$ polymorphism and the development of hypertension in a Chinese population.

\subsubsection{Aldosterone synthase}

The enzyme aldosterone synthase (CYP11B2) is the key enzyme in the final steps of aldosterone biosynthesis. It is encoded by the CYP11B2 gene located on chromosome 8q22 (Hilgers \& Schmidt, 2005, Brand et al., 1998). Several polymorphisms have been identified in the CYP11B2 gene (White \& Rainey, 2005). Among them, the promoter region C-344T polymorphism (rs id 1799998) is the best evaluated. This polymorphism either increases aldosterone to renin ratio in essential hypertensives or decreases aldosterone production, leading to sodium wasting and decreased excretion of potassium (Nicod et al., 2003, Matsubara et al., 2004). Furthermore, several studies have shown that the C-344T polymorphism is implicated in the risk of EH (Kumar et al., 2003, Gu et al., 2004) and other cardiovascular parameters. So the CYP11B2 gene is associated with the development of EH.

\subsection{Sodium system}

Several studies have examined the genetic influence on BP responses to dietary sodium and potassium intake in different populations. These studies have identified many candidate genes related to salt sensitivity of BP (Beeks et al., 2004). With the use of association or linkage studies, it appears that mutations increasing renal sodium reabsorption raise BP. The majority of these genes encode for renal ion channels and transporters or for components of hormonal or paracrine systems participating in the regulation of renal sodium reabsorption. All the genes involved in BP control are described in humans and in mice.

\subsubsection{Epithelial Sodium channel}

Epithelial sodium channel (Enac) is an amiloride sensitive epithelial sodium channel, composed of three subunits: $\alpha, \beta$, and $\gamma$ and encoded by different genes. SCNNIA gene coded for subunit $\alpha$, located on human chromosome 12p13, and involved in aldosteronism and pseudohypoaldosteronism type I. SCNNIB and SCNNIG genes coded respectively for $\beta$, and $\gamma$ subunits are related to monogenic form of salt sensitive hypertension (Kamida et al., 2004). The SCNNIA G2139 allele (Iwai, 2002, Wong, 1999) and Thr663Ala were reported to be associated with hypertension. A variety of mutations Gly589Ser, Thr594Met, Arg597His, Arg624Cys, Glu632Gly, Gly442Val and Val434Met has been shown in the SCNNIB gene and were implicated in the pathogenesis of systolic BP. In black individuals, the T594M mutation of the $\beta$ subunit of this gene increases the risk of hypertension (Baker et al., 1998, Dong et al., 2002). In addition, a Japanese study (Matsubara et al., 2002) indicated a linkage between systolic BP and microsatellite markers on chromosome 16p12.3, a region close to the gene coding for the $\beta$ and $\gamma$ subunits of Enac gene (Wong et al.; 1999). Another study (Hyun-Seok et al., 2010) identified several SNPs in SCNNIB, SCNNIG genes and showed a link between hypertension and these polymorphisms. A recent study (Zhao et al., 2011) reported multiple common SNPs in SCNNIG associated with BP response to sodium intervention. 


\subsubsection{Thiazide sensitive $\mathrm{Na}+\mathrm{Cl}-$ cotransporter}

The sodium chloride cotransporter (NCC) is the thiazide sensitive $\mathrm{Na}-\mathrm{Cl}$ cotranporter (TSC) located at the apical membrane of the distal convoluted tubule of the nephron (Plotkin et al., 1996), accounts for the absorption of $5 \%$ of the salt filtered at the glomerulus (Obermuller et al., 1995). The TSC gene, consisting of 26 exons that encode 1021 amino acid residus, is located on chromosome 16q13. Mutations in the human TSC gene is associated with a loss of TSC function, as seen in Gitelman's syndrome, an autosomal recessive disease that affects BP regulation (Simon et al., 1996). Several TSC gene variants have been reported in different populations. TSC gene polymorphisms (C2736A, C1420T, G816C) were identified in Swedish population and only homozygous A2736 and T1420 alleles were significantly associated with EH in this population (Melander et al., 2000), whereas the G2736A was related to hypertension in Japanese women. Other SNPs of TSC gene rs7204044 and rs13306673 were studied in Mongolian and Han populations. TSC gene rs 7204044 is a genetic factor for $\mathrm{EH}$ in these two ethnicities, but rs13306673 is a genetic factor for $\mathrm{EH}$ only in Han population (Chang et al., 2011).

\subsubsection{NEDD4L}

NEDD4L is a ubiquitin ligase that controls the expression of the kidney epithelial sodium channels. The NEDD4L gene located on human chromosome 18q21, is an attractive candidate gene in pathogenesis for hypertensive disorders (Pankow et al., 2000). Several SNPs, including a common SNP (rs4149601) known to result in abnormal splicing, are identified in African Americans, American whites, and Greek whites with EH (Russo et al., 2005). In Swedish subjects, the rs4149601 polymorphism and an intronic NEDD4L marker (rs2288774) were associated with systolic and diastolic BP, as a consequence of altered NEDD4L interaction with EnaC (Fava et al., 2006). Moreover, SNP (rs513563) in NEDD4L was associated with hypertension in both African and Caucasian whites (Russo et al., 2005). In Chinese Hans, another rs3865418 variant of NEDD4L gene was implicated in the prevalence of $\mathrm{EH}$ in this population (Wen et al., 2008).

\subsubsection{Na+ K+ IATPase}

The $\mathrm{Na}+\mathrm{K}+/$ ATPase (NAK) is an integral membrane protein responsible for establishing and maintaining the electrochemical gradients of $\mathrm{Na}+$ and $\mathrm{K}+$ across the plasma membrane. The NKA is characterized by a complex molecular heterogeneity consisting of $\alpha, \beta$ and $\gamma$ subunits. Four different a-polypeptides (a1, a2, a3, and a4) and three distinct $\beta$-isoforms $(\beta 1, \beta 2$, and $\beta 3)$ have been identified in mammalian. The a1 subunit is ubiquitous and predominates in the kidney, whereas the a2 subunit is most prevalent in the brain, heart, and muscle cells (Sweadner, 1989). The NAK catalytic subunit is encoded by multiple genes (Lalley et al., 1978) and separate genes encoding the a isoforms were identified in human (Shull \& Lingrel, 1987). In mouse, the gene encoding the a1 subunit (ATP1A1) has been assigned to mouse chromosome 3 . The a2 subunit gene (ATP1A2) is located on mouse chromosome 7 but the gene encoding the a 3 subunit is located on mouse chromosome 1 . The $\mathrm{Na}+\mathrm{K}+$ / ATPase $\beta 3$ subunit gene, which also exhibits a distinctive and complex tissuespecific pattern of expression (Mercer et al., 1986), maps to the same region of chromosome 1 , but is not tightly linked to the a3 subunit gene. Genetic studies have reported that the 3 'end of the gene for the a2 subunit (ATP1A2) and the $\beta$ subunits (ATP1B1) variants were 
associated with BP and hypertension (Shull et al., 1990, Kasantsev et al., 1992, Masharani \& Frossard, 1988, Glenn et al., 2001) but the Bgl II ATP1A1 polymorphism gene in the first intron is associated with diabetic neuropathy (Vague et al., 1997). In addition, SNPs has been described, close to the ATP1A1 gene (D1S453, $160 \mathrm{~kb})$ in Sardinian hypertensive and normotensive cohort (Glorioso et al., 2001). This study has identified an interaction of ATP1A1 and $\mathrm{Na}+\mathrm{K}+2 \mathrm{Cl}-$ Cotransporter genes in Human EH.

\subsection{Adducin}

Adducin is a cytoskeleton protein that promotes the binding of spectrin with actin and may modulate a variety of other cell functions such as ion transport (Matsuoka et al., 2000). It is an heterodimeric protein consisting of an $\alpha$-subunit and $\beta$-subunit or and a-subunit and $\gamma$ subunit, composed of three different subunits: adducin $\alpha, \beta$, and $\gamma$ which are encoded by three genes (ADD1, ADD2, ADD3) located on different chromosomes (Matsuoka et al., 2000). Adducin is one among the proteins that regulate $\mathrm{Na}+\mathrm{K}+/$ ATPase activity. Abnormalities in adducin by genetic mutation have been shown to influence the surface expression and maximum velocity of $\mathrm{Na}+\mathrm{K}+$ / ATPase and subsequently faster renal tubular $\mathrm{Na}+$ reabsorption (Mische et al., 1987). Clinical and experimental studies have reported that the a adducin gene mutations could affect renal $\mathrm{Na}+$ transport and explain a large proportion of BP variation (Bianchi et al., 1994, Barlassina et al., 1997), suggesting the involvement of mutated adducin variants in sodium-dependent hypertension. In animal models, single nucleotide polymorphisms (SNPs) in the ADD1 gene lead to increased tubular $\mathrm{Na}+$ reabsorption and hypertension (Tripodi et al., 1996). In humans, a guanine to thymine SNP at nucleotide 614 in exon 10 of the ADD1 gene (rs4961) leads to a glycine (Gly) to tryptophan (Trp) change at amino acid position 460. This polymorphism has been associated with elevated untreated BP (Lanzani et al., 2005) and hypertension salt sensitivity (Barlassina et al., 2000, Turner et al., 2003).

\subsubsection{ADD1}

The gene encoding human ADD1 is mapped onto the chromosome location 4p16.3. Two missense mutations G460W and S586C in the human a adducin gene (ADD1) were shown to be associated with EH (Cusi et al., 1997). The common molecular variant of the ADD1 gene causing the substitution of tryptophan instead of glycine (Gly460Trp) at amino acid position 460 was found to be associated with increased risk of hypertension in different population (Cusi et al., 1997, Ju et al., 2003).

\subsubsection{ADD2}

C1797T ADD2 gene silent polymorphism in exon 15 was reported to be associated with hypertension in post menopausal women (Wang et al., 2002), in oral contraceptive users and in high salt intake populations. In Polish and Russian subjects (Tikhonoff et al., 2003), BP and the prevalence of hypertension were associated with the C1797T polymorphism in the $\beta$ (ADD2), particularly in post menopausal women (Cwynar et al., 2005).

\subsubsection{ADD 3}

In ADD3 gene, the A to G substitution polymorphism located in intron 11 (IVS11 p386A>G -rs3731566) exists but neither previous publications nor genome browser databases 
provided any suggestion about its functional role. Previous studies on populations and patients have demonstrated that the ADD1 Gly460Trp polymorphism, alone or in combination with variation in the ADD3 (IVS11 p386A>G) or ACE (I/D) genes, influences the peripheral and central BP (Cwynar et al., 2005). Indeed, mean arterial pressure increased to the largest extent in patients carrying both the mutated ADD1Trp allele and the ADD3 GG genotype. Interaction between the ADD1 and ADD3 genes, which are located on different chromosomes, is in keeping with the heterodimeric structure of the adducin protein and strengthens the role of these genes compared with that of other loci mapping near to the adducin subunits (Kuznetsova et al., 2008).

\subsection{Natriuretic peptides}

The natriuretic peptide system (NP), with its diverse actions on renal and hemodynamic function and vasoactive hormone activity continues to attract attention as a potentially major regulator of body fluid volume and arterial pressure. The atrial natriuretic peptide (ANP), mainly produced by right atria in response to volume expansion, influences BP and body fluid homeostasis (Ogawa et al., 1995). This system consists of a family of three peptidic hormones A-type NP (ANP), B-type NP (BNP), and C-type NP (CNP) that interact with three receptors NP receptor A (NPRA), NP receptor B (NPRB) and NP clearance receptor (NPRC). The NPRC is encoded by the NPR3 gene and is a determinant of NP plasma concentration.

Genetic variants of the ANP system are involved in the etiology of hypertension (Rutlege et al., 1995, Kato et al., 2000), for this reason ANP is proposed as a candidate gene with saltsensitive HT in some studies (Rutlege et al., 1995, Ciechnowicz et al., 1997). Several polymorphisms have been described in the human ANP gene: -C664G, G1837A, T2238C polymorphisms and a microsatellite marker of both NPRA and BNP genes were characterized (Rubattu et al., 2006). The T2238C ANP and the G1837A ANP intronic gene polymorphisms have been reported to be associated with left ventricular mass in human EH (Schmieder et al., 1996) and increased risk of ischemic stroke (Rubattu \& Volpe, 2001). An I/D polymorphism at position 15129 of the 3'UTR of NPRA gene deletion variant is associated with hypertensive family history and higher systolic BP.

In the BNP gene, a variable number of tandem repeat (VNTR) polymorphism in the $5^{\prime}$ flanking region (-1241 nucleotides from the major transcriptional initiation site) was discovered. This VNTR polymorphism is a tandem repeat of the 4-nucleotide sequence TTTC appears to be a useful genetic marker of EH in females (Kosuge et al., 2007).

In CNP gene, four polymorphisms are identified : G733A, G1612C, G2347T and G2628A, two polymorphisms in the promoter region, one polymorphism in the coding region (exon 2) that accompanied an amino acid change from Gly to Val at amino acid position 61, and one polymorphism in the 3'-non coding region. Only the G2628A genotype in 3'-UTR was associated with BP and made greater contribution to hypertension (Ono et al., 2002). Overall these observations, suggested that atrial gene peptides could be considered candidate markers in $\mathrm{EH}$.

\subsection{Signal transduction pathways genes}

The basic signal transduction steps are mediated through specific receptors binding, G protein coupled receptors and some growth factors. Specific receptors like adrenergic 
receptors, glucagon receptor and growth factors as insulin-like growth factor 1 (IGF-I) genes are assumed to be important mediator in the pathophysiological response to BP increase. Mutation into the genes encoding signal transduction pathways have been associated with hypertension.

\subsubsection{G Proteins}

The main role of $G$ proteins is to translate signals from the cell surface into a cell (Siffert, 2003) to mediate the intracellular effects of many hormones and peptides. A polymorphism C3T at nucleotide 825 in exon 10 of the $\beta 3$ subunit of GTP binding protein (GNB3/C825T) has been identified (Bohm et al., 1997). This polymorphism is associated with enhanced intracellular signal transduction (Siffert et al., 1998) and has been reported to be associated with a variety of cardiovascular risk factors, including hypertension (Siffert et al., 1998, Schunkert et al., 1998, Benjafield et al., 1998), obesity (Siffert et al., 1999, Casiglia et al., 2008), diabetes (Bluthner et al., 1999) or dyslipidemia (Ishikawa et al., 2000, Hayakawa et al., 2007). A significantly higher frequency of the T allele has been identified in EH (Beige et al., 1999, Siffert, 1996). The mechanism whereby the $825 \mathrm{~T}$ variant may lead to hypertension remains unknown, but it may involve an increase of Na-H exchanger activity (Siffert, 1996) which enhanced renal sodium reabsorption and induced the BP increase. Several studies have demonstrated that the 825T allele of GNB3 is associated with hypertension (Benjafiel et al., 1998, Beige et al., 1999, Dong et al., 1999, Hengstenberg et al., 2001, Timberlake et al., 2001, Casiglia et al., 2008). Together, these studies highlight the importance of the GBN3/C825T variant gene in $\mathrm{EH}$.

\subsubsection{Glucagon receptor}

The glucagon is involved in the regulation of electrolyte and water homeostasis. The effects of glucagon are mediated through its binding to a specific receptor (GCG-R), a 480-amino acid protein, which belongs to the superfamily of $G$ protein-coupled transmembrane receptors (Laburthe et al., 1996). A Gly40Ser missense mutation in exon 2 of this receptor induced a lower affinity of the receptor for glucagon and a reduced cAMP response in transfected cells (Hansen et al., 1996). In humans, carriers of the mutation have a significantly lower increased plasma glucose concentration in response to glucagon infusion (Tonolo et al., 1997). A decrease in receptor activity in vivo might contribute to common EH by reducing the renal natriuretic effect of glucagon. Several studies have shown that the GCG-R plays a role in the predisposition to EH (Chambers \& Morris, 1996, Tonolo et al., 1997). Other studies have reported significant association of the Gly40Ser polymorphism in hypertensive women with family history of hypertension in both parents (Chambers \& Morris, 1996, Morris et al., 1997), whereas in French people, the Gly40Ser GCG-R variant was associated with hypertension only in men (Brand et al., 1999). Therefore, the glucagon receptor gene (GCG-R) could be a candidate gene for predisposition to human $\mathrm{EH}$.

\subsubsection{Insulin-like growth factor 1}

The insulin-like growth factor 1 (IGF-I) is assumed to be an important mediator in the pathophysiological response to increased BP in the vessel wall, and low circulating IGF-I levels have been associated with cardiovascular disease development (Juul et al., 2002). The absence of the $192 \mathrm{bp}$ allele in the promoter region of the IGF-I gene variant was associated 
with low circulating IGF-I levels and linked to systolic BP. An increased risk of developing atherosclerosis was shown in hypertensive subjects with this IGF-I polymorphism. The genetic variation of the IGF-I receptor may affect the susceptibility to ischemic stroke (Cheng et al., 2008) and the diversity of left ventricular structure in hypertensives (Horio et al., 2010). The (IGF-I) is a mediator in limiting the damaging effects of high BP on the EH.

\subsection{Noradrenergic system}

The sympathetic nervous system acts through two main groups of adrenergic receptors, $a$ and $\beta$ with several subtypes a1 and a 2 receptors and $\beta$ receptors have the subtypes $\beta 1, \beta 2$ and $\beta 3$, all linked to Gs proteins. The adrenergic system affects blood pressure by cardiac output and peripheral resistance regulation. Several studies have identified the implication of the $\beta$ adrenergic receptors in the genesis of hypertension and many candidate gene studies have evaluated the association of one or more polymorphisms of adrenergic receptors in cardiovascular diseases, suggesting involvement of adrenergic pathways in $\mathrm{EH}$.

\subsection{1 $\beta 1$-adrenergic receptor}

The $\beta 1$ adrenergic receptor (ADRB1), is a 7-transmembrane Gs protein coupled receptor. The ADRB1 is located on chromosome 10 (Hoehe et al., 1995) and is expressed in cardiac myocytes (Strader et al., 1994). Several polymorphisms of the ADRB1 exist, but two major single nucleotide Ser49Gly and Arg389Gly (Maqbool et al., 1999) are associated with BP. Arg389Gly variant is located in the intracellular cytoplasmic tail near the seventh transmembrane region of the receptor, which is a Gs-protein binding domain. The Arg389 polymorphism mediates a higher isoproterenol-stimulated adenylate cyclase activity than the Gly389 variant in vitro (Moore et al., 1999). The Ser49Gly polymorphism is located in the extracellular amino-terminal region of the receptor (Moore et al., 1999), but the potential functional consequence of this polymorphism is unknown. The genetic variants of the $\beta 1$ adrenergic receptor could play an important role in the development of hypertension, because the $\beta 1$ adrenergic receptor is essential in cardiac output regulation and the ADRB1 inhibitor reduces BP. Several studies have investigated the effects of these polymorphisms on resting haemodynamics and the incidence of hypertension, showing significantly higher diastolic BP and heart rates than siblings carrying either one or two copies of the 389G allele (Bengtsson et al., 2001).

\subsection{2 $\beta 2$-adrenergic receptor}

The $\beta 2$-adrenergic receptor (ADRB2) is responsible for vasodilatation in the vasculature via the cAMP pathway in smooth muscle cells or by release of nitric oxide (NO) from vascular endothelium (Eisenach et al., 2002). This receptor is implicated in the pathogenesis of hypertension. The ADRB2 gene located on chromosome 5q, is intronless, and codes for 413 amino acids. The most common SNPs in the ADRB2 gene include amino acid position 16, which contains either glycine or arginine (major/minor allele: Gly16/Arg), and amino acid position 27, which contains either glutamine or glutamic acid (Gln27/Glu). Some studies have shown that these two polymorphisms are associated with resistance to desensitization (Green et al., 1994, Green et al., 1995), but others have reported that the Gly16 variant ADRB2 gene is associated with EH in different populations (Lang et al., 1995, Svetkey et al., 1997, Kotanko et al., 1997, Timmermann et al., 1998, Lou Y et al., 2011). Moreover, another 
variant, the A46G in the ADRB2 gene is significantly associated with $\mathrm{EH}$ risk only in male among the Northern Han Chinese population (Lou et al., 2011). Therefore, the $\beta 2$ adrenergic receptor gene is considered a candidate gene for the development of $\mathrm{EH}$.

\subsection{3 $\beta 3$-adrenergic receptor}

The $\beta 3$-adrenergic receptor (ADRB3) gene is located on chromosome $8 p$ and codes for 396 amino acids. The ADRB3 gene contains a SNP that encodes either tryptophan or arginine (Trp64/Arg). This polymorphism is considered most relevant to lipolysis and thermogenesis. The ADRB3 genotype appears to have some influence in the development of obesity and appears to impact insulin resistance and the development of diabetes. So, The ADRB3 gene is not implicated in the risk of $\mathrm{EH}$.

\subsection{Endothelin system}

Potent vasoconstrictor peptides, composed of three member family of peptides, namely endothelin-1 (ET-1), endothelin-2 (ET-2), endothelin-3 (ET-3) and their receptors, have a convincing role in $\mathrm{EH}$. High circulating endothelin plasma levels have been reported in $\mathrm{EH}$ and genetic variants identified in the different component of endothelin system genes are involved in the etiology of hypertension.

\subsubsection{Endothelin 1}

Endothelin (ET)-1, produced by vascular endothelial cells, is a potent vasoconstrictor that acts as a modulator of vasomotor tone, cell proliferation, and vascular remodeling (Yanagisawa et al., 1988, Levin, 1995). The biological actions of ET-1 are mediated by two different receptors, ET-A receptor (ET-A) and ET-B receptor (ET-B). The interaction of ET-1 with ET-A in vascular smooth muscle cells is primarily responsible for ET-1-mediated vasoconstriction, whereas endothelial cell expressing ET-B promotes vasodilation (Haynes et al., 1995, Hirata et al., 1993). ET-1 is implicated in the pathogenesis of hypertension, heart failure, atherosclerosis, chronic kidney disease, and diabetes (MacGregor et al., 2000). High circulating endothelin plasma levels have been reported in EH. Human ET-1 gene is located on chromosome 6 and encodes a 21-amino acid peptide. Several SNPs in the endothelin system genes have been shown to have functional relevance and association with cardiovascular phenotypes and/or diseases (Taupenot et al., 2003). A G5665T polymorphism named Lys198Asn polymorphism of the preproendothelin-1 gene has been shown to be associated with higher BP in Caucasians and in Japanese populations with the T allele (Asai et al., 2001, Jin et al., 2003b). Therefore, the ET-1 is a candidate responsible for $\mathrm{EH}$.

\subsubsection{Endothelin 2}

ET-2 is expressed in the right atria. A single A985G base change in the '3-UTR of the ET-2 gene was identified in hypertensives when BP was assessed as a quantitative trait. The difference in genotype and allele frequencies between the extremes of BP suggests that the ET-2 locus influences the severity rather than the initial development of hypertension (Sharma et al., 1999). 


\subsubsection{Endothelin-converting enzyme}

Endothelin-converting enzyme (ECE) is a main component in endothelin (ET) biosynthesis, leading to the generation of ET-1, a potent vasoconstricting peptide, and contributing to BP control. Two different ECE genes, ECE-1 (Xu \& Yanagisawa, 1994) and ECE-2 (Emoto \& Yanagisawa, 1995), have been identified, but only ECE-1 expression is altered in human cardiovascular diseases. The gene is located at chromosome 1 (Albertin et al., 1996), has a length of $120 \mathrm{pb}$ and is consisting of 20 exons (Schweizer et al., 1997, Valdenaire et al., 1999, Funke-Kaiser et al., 2000). Human ECE-1 is expressed in four different isoforms: ECE-1a, ECE-1b, ECE-1c and ECE-1d (Shimada et al., 1995, Valdenaire et al., 1999) generated from an additional prometers (Valdenaire et al., 1995, Valdenaire et al., 1999). The ECE-1b isoform expressed in endothelial and vascular smooth muscle cells (Valdenaire et al., 1999, Orzechowski et al., 1997), may contribute to vascular ET generation and BP regulation.

Several polymorphisms have been described in the human ECE- $1 \mathrm{~b}$ promoter gene, but only combinations of two common variants within the 5'-flanking region (T-839G, C-338A) were significantly associated with high BP values in non-treated hypertensive females (FunkeKaiser et al., 2003). The -338A allele showed an increase in promoter activity compared with the wild-type promoter. Some studies conducted in African-American hypertensives have reported higher ECE-1 activity compared with white hypertensive patients (Grubbs et al., 2002), indicating that genetic variability in the ET system, e.g. ECE-1 gene, could be linked with severity of EH (Funke-Kaiser et al., 2003). So, the ECE-1 gene is a candidate gene in EH.

\subsubsection{Endothelin receptors}

ET-1 acts through two receptors ET-RA and ET-RB. Several single SNPs spanning the ET-RA gene were typed. The substitution of a thymine for a cytosine located in the untranslated part of exon 8 of the ET-RA gene was associated with pulse pressure and hypertension (Benjafield et al., 2003). In addition, an association was reported between genotype at the rs5335 (C+70G) SNP and night systolic BP and diastolic BP (Rahman et al., 2008). In this study the rs5335 (C+70G) polymorphism of the ET-RA receptor gene has small effects on the risk of hypertension. In another study (Ormezzano et al., 2005), the T allele of the ET-RA $\mathrm{A} / \mathrm{C}+1222 \mathrm{~T}$ polymorphism is associated with a reduction of baroreflex sensitivity in both healthy and hypertensive subjects. Likewise, a common polymorphism G1065A revealed that the AA+GA genotypes were significantly more frequent in salt-resistant than in saltsensitive individuals, suggesting a protective role for the A allele (Caprioli et al., 2008).

\subsubsection{Endothelial nitric oxide synthase}

Nitric oxide synthase (eNOS) synthesizes nitric oxide (NO), a potent vasodilator produced by endothelial cells. The eNOS gene (NOS3) is located at the 7q35-q36 region, has a length of $21 \mathrm{~kb}$ and consisted of 26 exons. Variants of this gene have been investigated for association with hypertension and other cardiovascular disorders (Casas et al., 2006). Among them, three polymorphisms have been widely examined for clinical relevance (Casas et al., 2006, Cooke et al., 2007). A G894T substitution in exon 7 resulting in a remplacement of Glu to Asp substitution at codon 298 (rs1799983), an insertion-deletion in intron 4 (4a/b) consisting of two alleles (the a-deletion which has four tandem 27-pb repeats and the b-insertion having five repeats), and a T786C substitution in the promotor region (rs2070744). Several 
studies have shown significant association of the eNOS3 polymorphisms gene with hypertension (Uwabo et al., 1998, M. Shoji et al., 2000, Jachymova et al., 2001, Hyndman et al., 2002). In the Chinese population, a significant and independent association between the eNOS-G894T polymorphism and EH has been shown (Men et al., 2001). In addition, a metaanalysis of 33 studies have examined the eNOS G894T, 4a4b, T-786C, and G23T polymorphisms and their relationship to susceptibility for hypertension, and reported that: the allele $4 \mathrm{~b}$ under a recessive model provided evidence of protection (Zintzaras et al., 2006). Thus, the eNOS gene is a risk factor for $\mathrm{EH}$.

\subsection{Apolipoproteins}

Apolipoproteins are large complexes of molecules that transport lipids through the blood. They play a major role in lipid metabolism. Genetic variations identified in apolipoprotein genes have been shown to be involved in the risk of $\mathrm{EH}$.

\subsubsection{Apolipoprotein B}

Apolipoprotein B (ApoB) is the main apolipoprotein of chylomicrons and low density lipoproteins (LDL), which occurs in the plasma in two main forms, ApoB48 and ApoB100. ApoB100 is synthesized in the liver and is present in very low density lipoproteins and their metabolic products. It is a principal ligand for low density lipoprotein (LDL) receptors (Boerwinkle et al., 1989) which mediate the uptake of LDL from the liver and peripheral cells. Like this, ApoB100 plays an important role in cholesterol homeostasis and a positive relationship has been established between coronary heart disease and LDL cholesterol with ApoB (Brunzell et al., 1984). The ApoB gene located at the 2p24 region (Knott et al., 1985), has a lengh of $42 \mathrm{~kb}$, is composed of 29 exons (Blackhart et al., 1986). The 3 ' end of the ApoB gene exhibits a variable number of tandemly repeated (VNTR) short, A+T rich DNA sequences (Knott et al., 1986). Several studies have reported that ApoB 3'VNTR alleles is associated with EH (Philippe et al., 1999, Friedl et al., 1990).

\subsubsection{Apolipoprotein C3}

Genetic variation in the apolipoprotein C (ApoC3) gene, is associated with an increased risk of coronary heart diseases (CDH) (Sacks et al., 2000). ApoC3 is a protein of 79 amino acids, a constituent of triglyceride rich lipoprotein, including very low density lipoprotein (VLDL), chylomicron (CM), and high density lipoprotein (HDL) (Windler et al., 1985). It inhibits the lipoprotein lipase-induced hydrolysis of those particles (Ashavaid et al., 2002). ApoC3 exists in three different isoforms, according to the sialylation degree of the protein. Previous studies have shown that low ApoC3 levels may be associated with reduced CHD risk. Two polymorphisms located at positions -455 ( $\mathrm{T}$ to $\mathrm{C}$ ) and -482 ( $\mathrm{C}$ to $\mathrm{T}$ ) in the $5^{\prime}$ ApoC3 gene promoter region, have been shown to be associated with elevated levels of serum triglyceride and with a negative insulin response element (Dammerman et al., 1993). Another study has reported that the ApoC3 3206GG genotype was associated with a decrease in diastolic BP while the ApoC3 $-482 \mathrm{~T}$ allele was associated with a decrease in pulse pressure levels.

\subsubsection{Apolipoprotein E}

Apolipoprotein E (ApoE) gene situated on chromosome 19, appears in humans in three different forms named E2, E3 and E4 differing from each other by amino acid substitution in 
two various positions (varying Cys112Arg and Arg158Cys) and coded by three alleles $\varepsilon 2$, ع3 and $\varepsilon 4$ at a single gene locus. ApoE polymorphism is one of the common genetic factors responsible for inter-individual variations in lipid and lipoprotein levels. ApoE4 has a higher and ApoE2 much lower affinity to the LDL receptor. The $\varepsilon 2$ allele is associated with the lowest while the $\varepsilon 4$ allele with the highest plasma cholesterol levels. Therefore, ApoE4 may be considered atherogenic (Curtiss \& Boisvert, 2000), while ApoE2 seems to show a protective effect (Davignon et al., 1988). Some study has reported correlation between ApoE4 polymorphism and the incidence of CAD (Baroni et al., 2003). ApoE also seems to play a role in BP regulation. The $\varepsilon 4$ allele influences the BP increasing effect of alcohol consumption. This gene environment interaction may have marked implications for the prevention and treatment of hypertension (Kauma et al., 1998).

\subsubsection{Lipoprotein lipase}

Lipoprotein lipase (LPL) is the main enzyme responsible for the hydrolysis of triglyceride (TG) present in circulating lipoproteins, and regulates high density lipoprotein concentrations. LPL gene located on chromosome 8p22 (Sparkes et al., 1987), has a length of $30 \mathrm{~kb}$ (Deeb \& Peng, 1989), is composed of 10 exons. Mutations in locus intron 6 of LPL gene (Oka et al., 1989, Zuliani \& Hobbs, 1990) lead to hypertriglyceridemia, dyslipidemia leading to various disorders as coronary artery disease, hypertension and obesity. The association betweeen hypertension and the LPL locus $(8 \mathrm{p} 22)$ was reported by several studies (Chen et al., 2005, Yang et al., 2003). Significant evidence for linkage of systolic BP, but not diastolic $\mathrm{BP}$ has been associated with LPL locus located on the short arm of chromosome 8 (8p22) (Du-An et al., 1992). Another study has identified a S447X polymorphism in exon 9 of LPL gene that results from replacement of serine amino acid with a stop codon creating a restriction site. This study has reported that the more common SS genotype is associated with a lower LPL activity compared with the infrequent SX/XX genotype and carriers of (SS) genotype were at high risk of developing hypertension (Salah et al., 2009). Another study, has suggested that a high concentration of triglyceride and/or low concentration of HDL-cholesterol are associated with high systolic BP and pulse pressure in hypertensive patients with the X447 allele of the LPL gene (Liu et al., 2004). Therefore, the LPL gene is considered as a candidate gene that could contribute to the development of $\mathrm{EH}$.

\subsection{Cytokines}

Interleukin-6 (IL-6) is a multifunctional cytokine involved in inflammation, potentially influencing BP. The human IL-6 gene is located on chromosome 7p21 (Bowcock et al., 1988). Genetic variations of the IL-6 gene have been reported, and the commonly studied polymorphism is the functional variant $-174 \mathrm{G}>\mathrm{C}$ (Fishman et al., 1998). Association of this polymorphism with coronary artery diseases has been reported in some studies (Rauramaa et al. 2000, Berg et al., 2009, Pola et al 2002). In addition, this polymorphism has been shown to be associated in vivo with high levels of IL-6 (Jenny et al., 2002, Brull et al., 2001). Previous studies (Ridker et al., 2000, Chae et al., 2001) have reported that increased IL-6 levels is correlated with high BP and may be an independent risk factor for hypertension. Moreover, in Japanese women, a weak association was reported between hypertension and other IL-6 gene promotor variants, the C/G substitution at -634 , the G/A substitution at 4391 in a 3- non-coding portion of exon 5, and the A/T variation in the -447 position (Nakajima et al., 1999). 


\subsection{Neuropeptide $Y$}

Neuropeptide Y (NPY) is a sympathetic cotransmitter with catecholamines (Takiyyuddin et al., 1994). It exhibits a vasoconstricting action and has multiple receptors, Y1-Y5. NPY interacts with the Y1 receptor (NPY1R) to control adrenergic activity and BP (Michalkiewicz et al., 2005). The gene encoding the NPY1R coupled with G proteins is located on chromosome 4q31.3-q32 (Eva et al., 2006). Genetic variation at the NPY1R locus has implications for heritable autonomic control of the circulation, and systemic hypertension (Wang et al., 2009). Several NPY1R variants have been identified in EH. Both the promoter A-585T and the 3'-UTR A+1050G variants had important effects upon both diastolic BP and systolic BP and interacted to determine diastolic BP. Homozygous for both the promoter variant major allele (A/A at A-585T) and the 3'-UTR variant minor allele (G/G at A +1050G) had dramatic BP elevation (Wang et al., 2009). Moreover, other studies have reported that hypertension is influenced by the NPY T1128C polymorphism in South Indian population (Bhaskar et al., 2010) and in a Swedish hypertensive population (Wallerstedt et al., 2004). Therefore, the NPY gene is a candidate marker in EH.

\section{Gene-gene interactions in EH}

Large numbers of gene variants have been described in $\mathrm{EH}$, and the pathogenic role of genegene interaction has received increasing attention. Some study (Bell et al., 2006) has reported that the presence of epistatic interactions and locus heterogeneity in the underlying genetics of hypertension may explain the lack of replicated linkage (Williams, 2004). The developped linkage tests for multiple susceptibility loci applied to human data (Cordell, H.J., 1995, Cox, N.J., 1999) have contributed to advance of the gene-gene interactions studies, but these methods have examined only pre-selected regions. Thus, by two dimensional genome-scan approach, Bell et al., (2006) have identified significant evidence for loci on chromosomes 5, 9, $11,15,16$ and 19, which influence hypertension when gene-gene interactions are taken into account (5q13.1 and 11q22.1, two-locus lod score 5 5.72; 5q13.1 and 19q12, two-locus lod score 5 5.35; 9q22.3 and 15q12, two-locus lod score 5 4.80; 16p12.3 and 16q23.1, two-locus lod score 5 4.50). Another study (Williams et al., 2000) has examined the effects of allele interactions at 4 candidate loci. Three of the loci are in the renin-angiotensin-system: angiotensinogen, ACE, and AGTR1, and they have been associated with hypertension. The fourth locus studied is a previously undescribed locus, named FJ. In total, seven polymorphic sites at these loci were analyzed for their association with hypertension in normotensive and hypertensive age-matched individuals. There were no significant differences between the 2 phenotypic classes with respect to either allele or genotype frequencies. In this report, when authors have tested for nonallelic associations (linkage disequilibrium), they found that of the 120 multilocus comparisons, 16 deviated significantly from random in the hypertensive class, but there were no significant deviations in the normotensive group. This study suggests that genetic interactions between multiple loci rather than variants of a single gene underlie the genetic basis of hypertension. The relation of many polymorphisms has been examined also in Chinese hypertensive patients (Dongfeng et al., 2006), in several candidate genes with the risk of hypertension: (1) reninangiotensin-aldosterone system, including ACE, AGTR1, and CYP11B2, (2) sympathetic nervous system, including a-1 adrenergic receptor 1A (ADRA1), ADRB2, and tyrosine hydroxylase (TH); (3) lipoprotein metabolism, including LPL; (4) intracellular messengers, including GNB3 and NOS3 ; and (5) sodium and electrolyte balance, including G protein- 
coupled receptor kinase 4 (GRK4) and protein kinase lysine- deficient 4 (WNK4). Both single-locus and multilocus analyses revealed that two genes from the sympathetic system (TH and ADRB2) and one gene affecting the sodium balance (GRK4) were independently associated with the significant risk of hypertension in the Chinese Han population. In addition to these 3 individual predictors, an interaction between CYP11B2 and AGTR1, both from RAAS, was also found to be involved in the relationship with hypertension. These findings support the recognized understanding that complex genetic interactions account for hypertension risk. Additional studies have genotyped hypertensives at the AGT M235T, ACE I/D, CYP11B2 C-344T, REN, AGTR1 and/or ADD loci, have reported that combinations of polymorphisms at several of these loci steadily increase the odds ratio of predicting hypertension (Agachan B et al., 2003, Vasku A et al., 1998, Tsai CT et al., 2003). Another study (Tomaszewski et al., 2006) revealed epistatic interaction between ADRB2 and NPY in regulation of LDL levels in hypertensive subjects. The effect of NPY locus appears to be altered by ADRB2. Specifically, Leu7Leu genotype within NPY SNP was associated with increased concentrations of LDL only in the presence of Arg16Gln27. Taken together all these studies provide evidence that several functional polymorphisms within candidate genes act individually or together in the etiology of EH.

\section{Conclusion}

The actual number of candidate genes detected in EH studies reinforced the highly polygenic nature of this disease. Knowing the genes responsible for this condition is an important prerequisite to prevent the expression of these disease markers related to lifestyle, especially for predisposed subjects at risk. From a large series of studies conducted in humans and animals, the renin-angiotensin-aldosterone system constitued risk genes and other systems like sodium system genes, signal transduction system genes, endothelial system genes, and neurohormonal and adrenergic genes were involved in genetic predisposition of EH. In addition, several lessons could be learned from these genetic studies and applied to other additional candidate genes that would be necessary to identify in EH. Actual strategies used for genetic studies showed some limitations. As well the candidate gene strategy (which assumes that a given gene, or a set of genes involved in a specific function, might contribute in BP variation) as linkage and/or association studies suffered from limited sample sizes and a low prior probability of the selected candidate genes being associated with hypertension. Moreover, the sequence variants influencing the phenotype of $\mathrm{EH}$ have remained elusive, but with better mapping techniques, better phenotyping methods and systems biology approach, and potential gene-gene interactive model, we should begin to discover those variants that could lead to its enhanced prevention, detection, and treatment of $\mathrm{EH}$.

\section{References}

Agachan, B. ; Isbir, T. ; Yilmaz , H. \& Akoglu E. (2003). Angiotensin converting enzyme I/D, angiotensinogen T174M-M235T and angiotensin II type 1 receptor A1166C gene polymorphisms in Turkish hypertensive patients. Exp Mol Med 35: 545-9

Ahmad, U.; Saleheen, D.; Bokhari, A. \& Frossard, PM. (2005). Strong association of a renin intronic dimorphism with essential hypertension. Hypertens Res 28: 339-344 
Albertin, G.; Rossi, GP.; Majone, F.; Tiso, N.; Mattara, A.; Danieli, GA.; Pessina, AC. \& Palu, G. (1996). Fine mapping of the human endothelin-converting enzyme gene by fluorescent in situ. Biochem Biophys Res Commun 221:682-687

Alfakih, K.; Maqbool, A.; Sivananthan, M.; Walters, K.; Bainbridge, G.; Ridgway, J.; Balmforth, AJ. \& Hall, AS. (2004). Left ventricular mass index and the common, functional, X-linked angiotensin II type 2 receptor gene polymorphism (-1332G/A) in patients with systemic hypertension. Hypertension 43:1189

Allikmets, K.; Patrik, T. \& Viigimaa, M. (1999). The renin-angiotensin system in essential hypertension: Associations with cardiovascular risk. Blood Press 8:70-78

Asai, Y.; Ohkubo, T.; Katsuya, T.; Higaki, J.; Fu, Y.; Fukuda, M.; Hozawa, A.; Matsubara, M.; Kitaoka, H.; Tsuji, I.; Araki, T.; Satoh, H.; Hisamichi, S.; Imai, Y. \& Ogihara, T. (2001). Endothelin 1 gene variant associates with blood pressure in overwitht people. Hypertension 33:1169-1174

Ashavaid, TF.; Shalia, KK.; Kondkar, AA.; Todur, SP.; Nair, KG. \& Nair, SR. (2002). Gene polymorphism and coronary risk factors in Indian population. Clin Chem Lab Med 40:975- 985

Baker, EH.; Dong, YB. \& Sagnella, GA. (1998). Association of hypertension with T594M mutation in beta subunit of epithelial sodium channels in black people resident in London. Lancet 351:1388-1392

Barlassina, C.; Citterio, L.; Bernardi, L.; Buzzi, L.; D’Amico, M.; Sciarrone, T. \& Bianchi, G. (1997) Genetics of renal mechanisms of primary hypertension: the role of adducin. J Hypertens 15:1567-1571.

Barlassina, C.; Schork, NJ.; Manuta, P.; Citterio, L.; Sciarronre, M.; Lanella, G.; Bianchi, G. \& Cusi, D. (2000). Synergistic effect of alpha-adducin and ACE genes causes blood pressure changes with body sodium and volume expansion. Kidney Int 57:10831090

Baroni, MG.; Berni, A.; Romeo, S.; Arca, M.; Tesorio, T.; Sorropago, G.; Di Mario, U. \& Galton, DJ. (2003). Genetic study of common variants at the Apo E, Apo AI, Apo CIII, Apo B, lipoprotein lipase (LPL) and hepatic lipase (LIPC) genes and coronary artery disease (CAD): variation in LIPC gene associates with clinical outcomes in patients with established CAD. BMC Med Genet 4:8

Beeks, E.; Kessels, AG.; Kroon, AA.; van der Klauw, MM. \& de Leeuw, PW. (2004). Genetic predisposition to salt-sensitivity: a systematic review. J Hypertens 22:1243-1249

Beige, J.; Hohenbleicher, H.; Distler, A. \& Sharma, AM. (1999). G-Protein $\beta 3$ subunit C825T variant and ambulatory blood pressure in essential hypertension. Hypertension 33:1049-51

Bell, JT.; Wallace, C.; Dobson, R.; Wiltshire, S.; Mein, C.; Pembroke, J.; Brown, M.; Clayton, D.; Samani, N.; Dominiczak, A.; Webster, J.; Lathrop, GM.; Connell, J.; Munroe, P.; Caulfield, M. \& Farral M. (2006). Two-dimensional genome-scan identifies novel epistatic loci for essential hypertension. Hum Mol Genet 15: 1365-1374

Bengtsson, K.; Orho-Melander, M.; Lindblad, U.; Melander, O.; Bøg-Hansen, E.; Ranstam, J.; Råstam, L.; Groop, L. (1999). Polymorphism in the angiotensin converting enzyme but not in the angiotensinogen gene is associated with hypertension and type 2 diabetes: the Skaraborg Hypertension and Diabetes Project. J Hypertens 17:1569-1575 
Benjafield, AV.; Jeyasingam, CL.; Nyholt, DR.; Griffiths, LR. \& Morris, BJ. (1998). G-protein $\beta 3$ subunit gene (GNB3) variant in causation of essential hypertension. Hypertension 32:1094-1097

Benjafield, AV.; Katyk, K. \& Morris, BJ. (2003). Association of EDNRA, but not WNK4 or FKBP1B, polymorphisms with essential hypertension. Clin Genet 64(5):433-8.

Berg, KK.; Madsen, HO.; Garred, P.; Wiseth, R.; Gunnes, S. \& Videm, V. (2009). The additive contribution from inflammatory genetic markers on the severity of cardiovascular disease. Scand J Immunol 69:36-42

Bhaskar, LV.; Thangaraj, K.; Non, AL.; Praveen, KK.; Pardhasaradhi, G.; Singh, L. \& Rao, VR. (2010). Neuropeptide Y gene functional polymorphism influences susceptibility to hypertension in Indian population. J Hum Hypertens 24(9):617-22

Bianchi, G.; Tripodi, G.; Casari, G. ; Salardi, S. ; Barber, BR.; Garcia, R. ; Leoni, P. ; Torielli, L. ; Cusi, D. ; Ferrandi, M. (1994). Two point mutations within the adducin genes are involved in blood pressure variation. Proc Natl Acad Sci USA 91:3999-4003

Blackhart, BD.; Ludwig, EM.; Pierotti, VR.; Caiati, L.; Onasch, MA.; Wallis, SC.; Powell, L.; Pease, R.; Knott, TJ. \& Chu, ML. (1986). Structure of the human apolipoprotein B gene. Biol Chem 33:15364-15367

Bluthner, M.; Schmidt, S.; Siffert, W;. Knigge, H.; Nawroth, P. \& Ritz, E. (1999). Increased frequency of $\mathrm{G}$ protein $\beta 3$-subunit $825 \mathrm{~T}$ allele in dialyzed patients with type 2 diabetes. Kidney Int 55:1247-50

Boerwinkle, E.; Xiong, W.; Fourest, E. \& Chan, L. (1989). Rapid typing if tandemly repeated hypervariable loci by the polymerase chain reaction: application to the apolipoprotein B 3' hypervariable region. Proc Natl Acad Sci USA 86:212-6

Bohm, SK.; Grady, EF. \& Bunnet, NW. (1997). Regulatory mechanisms that modulate signaling by G-protein-coupled receptors. Biochem J 322:1-18

Bonnardeaux, A.; Davis, E.; Jeunemaître, X. ; Fery, I. ; Charru, A. ; Clauser, E. ; Tiret, L. ; Cambien, F. ; Corvol, P. \& Soubrier, F. (1994). Angiotensin II type I receptor gene polymorphisms in human essential hypertension. Hypertension 24:63-9

Bowcock, AM.; Kidd, JR.; Lathrop, GM.; Daneshvar, L.; May, LT.; Ray, A.; Sehgal, PB.; Kidd, KK. \& Cavalli-Sforza, LLQ. (1988). The human 'interferon-beta 2/hepatocyte stimulating factor/interleukin- 6 ' gene: DNA polymorphism studies and localization to chromosome 7p21. Genomics 3: 8-16

Brand, E.; Bankir, L.; Plouin, PF. \& Soubrier, F. (1999). Glucagon Receptor Gene Mutation (Gly40Ser) in human essential hypertension the PEGASE study. Hypertension 34:1517

Brand, E.; Chatelain, N.; Mulatero, P.; Féry, I.; Curnow, K.; Jeunemaitre, X.; Corvol, P.; Plouin, PF.; Cambien, F.; Pascoe, L.; Soubrier, F. (1998). Structural analysis and evaluation of the aldosterone synthase gene in hypertension. Hypertension 32: 198204

Brull, DJ.; Montgomery, HE.; Sanders, J.; Dhamrait, S.; Luong, L.; Rumley, A.; Lowe, GD. \& Humphries, SE. (2001). Interleukin-6 gene $-174 \mathrm{~g}>\mathrm{c}$ and $-572 \mathrm{~g}>\mathrm{c}$ promoter polymorphisms are strong predictors of plasma interleukin-6 levels after coronary artery bypass surgery. Arterioscler Thromb Vasc Biol 21:1458-63

Brunzell, JD.; Sniderman, AD.; Albers, JJ. \& Kwiterovich, PO. (1984). Apoproteins B and AI and coronary artery disease in humans. Arteriosclerosis 4:79-83 
Caprioli, J.; Mele, C.; Mossali, C.; Gallizioli, L.; Giacchetti, G.; Noris, M.; Remuzzi, G. \& Benigni, A. (2008). Polymorphisms of EDNRB, ATG, and ACE genes in saltsensitive hypertension. Can J Physiol Pharmacol 86:505-10

Casas, JP.; Cavalleri, GL.; Bautista, LE. ; Smeeth, L. ; Humphries, SE. \& Hingorani, AD. (2006). Endothelial nitric oxide synthase gene polymorphisms and cardiovascular disease: a HUGE review. Am J Epidemiol 164:921-35

Casiglia, E.; Tikhonoff, V.; Caffi, S.; Martini, B.; Guidotti, F.; Bolzon, M.; Bascelli, A.; D'Este, D.; Mazza, A. \& Pessina, AC. (2008). Effects of the C825T polymorphism of the GNB3 gene on body adiposity and blood pressure in fertile and menopausal women: a population-based study. J Hypertens 26:238-43

Chae, CU.; Lee, RT.; Rifai, N \& Ridker, PM. (2001). Blood pressure and inflammation in apparently healthy men. Hypertension 38:399-403

Chambers, SM. \& Morris, BJ. (1996). Glucagon receptor gene mutation in essential hypertension. Nature Genet 12:122. Letter

Chang, PY.; Zhao, LG. \& Su, XL. (2011). Association of TSC gene variants and hypertension in Mongolian and Han populations. Genet Mol Res 10:902-909

Chaves, FJ.; Pascual, JM.; Rovira, E.; Armengod, ME. \& Redon, J. (2001). Angiotensin II AT1 receptor gene polymorphism and microalbuminuria in essential hypertension. Am J Hypertens 14:364-70

Chen, P.; Jou, YS.; Fann, CS.; Chen, JW.; Wu, SY. \& Pan, WH. (2005). Lipoprotein lipase gene is linked and associated with hypertension in Taiwan young-onset hypertension genetic study. J Biomed Sci 12:651-8

Cheng, J.; Liu, J.; Li, X.; Peng, J.; Han, S.; Zhang, R.; Xu, Y. \& Nie, S. (2008). Insulin-like growth factor-1 receptor polymorphism and ischemic stroke: a case-control study in Chinese population. Acta Neurol Scand 118:333-8

Ciechanowicz, A.; Kurzawski, G.; Widecka, K.; Goździk, J.; Adler, G. \& Czekalski, S. (1997). The T--C mutation of the nucleotide 2238 in the gene of atrial natriuretic peptide (ANP) precursor and heterogeneity of sodium-sensitive hypertension. Preliminary report. Pol Arch Med Wewn 98:501-9

Cooke, GE.; Doshi, A. \& Binkely, PF. (2007). Endothelial nitric oxide synthase gene: prospects for treatment of heart disease. Pharmacogenomics 8:1723-1734.

Cordell, HJ.; Todd, JA.; Bennett, ST.; Kawaguchi, Y. \& Farrall, M. (1995) Two-locus maximum lod scor analysis of a multifactorial trait: joint consideration of IDDM2 and IDDM4 with IDDM1 in type 1 diabetes. Am J Hum Genet 57: 920-934

Cox, NJ.; Frigge, M.; Nicolae, DL.; Concannon, P.; Hanis, CL.; Bell, GI. \& Kong, A. (1999) Loci on chromosomes 2 (NIDDM1) and 15 interact to increase susceptibility to diabetes in Mexican Americans. Nat Genet :21, 213 -215

Curtiss, LK. \& Boisvert, WA. (2000). Apolipoprotein E and atherosclerosis. Curr Opin Lipidol 11:243-251

Cusi, D.; Barlassina, C.; Azzani, T.; Casari, G.; Citterio, L.; Devoto, M.; Glorioso, N.; Lanzani, C.; Manunta, P.; Righetti, M.; Rivera, R.; Stella, P.; Troffa, C.; Zagato, L. \& Bianchi, G. (1997). Polymorphisms of alpha-adducin and salt sensitivity in patients with essential hypertension. Lancet 349:1353-1357

Cwynar, M.; Staessen, JA.; Ticha, M.; Nawrot, T.; Citterio, L.; Kuznetsova, T.; Wojciechowska, W.; Stolarz, K.; Filipovský, J.; Kawecka-Jaszcz, k.; Grodzicki, T.; Struijker-Boudier, HA.; Thijs, L.; Van Bortel, L. \& Bianchi, G. (2005). On behalf of the European Project on Genes in Hypertension (EPOGH) Investigators. Epistatic 
interaction between $a$ and $\gamma$-adducin influences peripheral and central pulse pressure in White Europeans. J Hypertens 23:961-969

Dammerman, M.; Sandkuijl, LA.; Halaas, JL.; Chung, W. \& Breslow, JL. (1993). An apolipoprotein CIII haplotype protective against hypertriglyceridemia is specified by promoter and 3' untranslated region polymorphisms. Proc Natl Acad Sci USA 90:4562-4566

Davignon, J.; Gregg, RE. \& Sing, CF. (1988) Apolipoprotein E polymorphism and atherosclerosis. Arteriosclerosis 8:1-21

Deeb, SS. \& Peng, R. (1989). Structure of the human lipoprotein lipase gene. Biochemistry 28: 4131-4135

Delles, C.; Erdmann, J.; Jacobi, J,.; Fleck, E.; Regitz-Zagrosek, V. \& Schmieder, RE. (2000). Lack of association between polymorphisms of angiotensin II receptor genes and response to short-term angiotensin II infusion. J Hypertens 18:1573-8

Dong, Y.; Zhu, H.; Sagnella, GA.; Carter, ND.; Cook, DG. \& Cappuccio, FP. (1999). Association between the C825T polymorphism of the $\mathrm{G}$ protein beta3-subunit gene and hypertension in blacks. Hypertension 34:1193-6

Dong, YB.; Plange-Rhule, J.; Owusu, I.; Micah, F;. Eastwood, JB.; Carter, ND.; Saggar-Malik, AK.; Cappuccio, FP. \& Jeffery, S. (2002). T594M mutation of the beta-subunit of the epithelial sodium channel in Ghanaian populations from Kumasi and London and a possible association with hypertension. Genet Test 6:63-5

Dongfeng, G.; Shaoyong, S.; Dongliang, G.; Shufeng, C.; Jianfeng, H.; Biao, L.; Runsheng, C. \& Boqin Q. (2006). Association study with 33 single-nucleotide polymorphisms in 11 candidate genes for hypertension in Chinese. Hypertension 47:1147-1154

Doria, A.; Onuma, T.; Warram, JH. \& Krolewski, AS. (1997). Synergistic effect of angiotensin II type 1 receptor genotype and poor glycaemic control on risk of nephropathy in IDDM. Diabetologia 40:1293-9

Du-An, W.; Xiangdong, B.; Craig, H.; Warden, D.; Shen, DC.; Jeng, CY.; Wayne, HH.; Sheu, M.; Fuh, MT.; Tomohiro, K.; Victor, JD.; Gerald, MR.; Aldons, JL.; Jerome, IR. \& Chen, YD. (1992). Quantitative Trait Locus Mapping of Human Blood Pressure to a Genetic Region at or near the Lipoprotein Lipase Gene Locus on Chromosome 8p22. J Clin Invest 97: 2111-2118

Eisenach, JH.; Clark, ES.; Charkoudian, N.; Dinenno, FA.; Atkinson, JL.; Fealey, RD.; Dietz, NM. \& Joyner, MJ. (2002). Effects of chronic sympathectomy on vascular function in the human forearm. J Appl Physiol 92:2019-2025

Emoto, N. \& Yanagisawa, M. (1995) Endothelin-converting enzyme-2 is a membrane-bound, phosphoramidon-sensitive metalloprotease with acidic $\mathrm{pH}$ optimum. J Biol Chem 270:15262-15268

Erdmann, J., Guse, M., Kallisch, H., Fleck, E. \& Regitz-Zagrosek, V. (2000). Novel intronic polymorphism $(+1675 \mathrm{G} / \mathrm{A})$ in the human angiotensin II subtype 2 receptor gene. Hum Mutat 15: 487

Erdmann, J.; Riedel, K.; Rohde, K.; Folgmann, I.; Wienker, T.; Fleck, E. \& Regitz-Zagrosek, V. (1999). Characterization of polymorphisms in the promoter of the human angiotensin II subtype 1 (AT1) receptor gene. Ann Hum Genet 63:369-74

Eva, C.; Serra, M.; Mele, P.; Panzica, G. \& Oberto, A. (2006). Physiology and gene regulation of the brain NPY Y1 Receptor. Front Neuroendocrinol 27:308-339 
Fang, YJ.; Deng, HB.; Thomas, GN.; Tzang, CH.; Li, CX.; Xu, ZL.; Yang, M. \& Tomlinson, B. (2010). Linkage of angiotensinogen gene polymorphisms with hypertension in asibling study of Hong Kong Chinese. J Hypertens 28: 1203-1209

Fava, C.; von Wowern, F.; Berglund, G.; Carlson, J.; Hedblad, B.; Rosberg, L.; Burri, P.; Almgren, P. \& Melander, O. (2006). 24-h ambulatory blood pressure is linked to chromosome 18q21-22 and genetic variation of NEDD4L associates with crosssectional and longitudinal blood pressure in Swedes. Kidney Int 70:562-9

Fishman, D.; Faulds, G.; Jeffery, R.; Mohamed-Ali, V.; Yudkin, JS.; Humphries, S \& Woo, P. (1998). The effect of novel polymorphisms in the interleukin-6 (IL-6) gene on IL-6 transcription and plasma IL-6 levels, and an association with systemic-onset juvenile chronic arthritis. J Clin Invest 102:1369-76

Friedl, W.; Ludwig, EH.; Paulweber, B.; Sandhofer, F. \& McCarthy, BJ. (1990). Hypervariability in a minisatellite $3^{\prime}$ of the apolipoprotein $B$ gene in patients with coronary heart disease compared with normal controls. J Lipid Res 31:659-665

Frossard, PM.; Malloy, MJ.; Lestringant, GG. \& Kane, JP. (2001). Haplotypes of the human renin gene associated with essential hypertension and stroke. J Hum Hypertens 15: 49-55

Funke-Kaiser, H.; Bolbrinker, J.; Theis, S.; Lemmer, J.; Richter, CM.; Paul, M. \& Orzechowski, HD. (2000). Characterization of the c-specific promoter of the gene encoding human endothelin-converting enzyme-1 (ECE-1). FEBS Lett 466-310-316

Funke-Kaiser, H.; Reichenberger, F.; Ko“pke, K.; Herrmann, SM.; Pfeifer, J.; Orzechowski, HD.; Zidek, W.; Paul, M. \& Brand, E. (2003). Differential binding of transcription factor E2F-2 to the endothelin-converting enzyme-1b promoter affects blood pressure regulation. Hum Mol Genet 12:423-33

Gaillard, I.; Clauser, E. \& Corvol, P. (1989). Structure of human angiotensinogen gene. DNA 8:87-99

Glenn, B.S;. Stewart, WF.; Schwartz, BS. \& Bressler, J. (2001). Relation of alleles of the sodium-potassium adenosine triphosphatase a2 gene with blood pressure and lead exposure. Am J Epidemiol 153:537-45

Glorioso, N.; Filigheddu, F.; Troffa, C.; Soro, A.; Parpaglia, PP.; Tsikoudakis, A.; Meyers, RH.; Herrera, VLM. \& Ruiz-Opazo, N. (2001). Interaction of a1-NaK-ATPase and $\mathrm{NaK} 2 \mathrm{Cl}$-cotransporter genes in human essential hypertension. Hypertension 38:204209

Gopi-Chand, M.; Srinath, J.; Rao, RS.; Lakkakula, BV.; Kumar, S. \& Rao, VR. (2011). Association between the M268T polymorphism in the angiotensinogen gene and essential hypertension in a South Indian Population. Biochem Genet 49:474-82

Green, SA.; Turki, J.; Bejarano, P.; Hall, IP. \& Liggett, SB. (1995). Influence of beta 2adrenergic receptor genotypes on signal transduction in human airway smooth muscle cells. Am J Respir Cell Mol Biol 13:25-33

Green, SA. Turki, J.; Innis, M. \& Liggett, SB. (1994). Amino-terminal polymorphisms of the human beta 2-adrenergic receptor impart distinct agonistpromoted regulatory properties. Biochemistry 33:9414-9419

Grubbs, AL.; Anstadt, MP. \& Ergul, A. (2002) Saphenous vein endothelin system expression and activity in African American patients. Arterioscler Thromb Vasc Biol 22:1122-1127

Gu, D.; Ge, D.; He, J.; Li, B.; Chen, J.; Liu, D.; Chen, J. \& Chen, R. (2004). Haplotypic analyses of the aldosterone synthase gene CYP11B2 associated stage-2 hypertension in northern Han Chinese. Clin Genet 66 :409-16 
Hansen, LH.; Abrahamsen, N.; Hager, J.; Jelinek, L.; Kindsvogel, W.; Froguel, P. \& Nishimura, E. (1996). The Gly40Ser mutation in the human glucagon receptor gene associated with NIDDM results in a receptor with reduced sensitivity to glucagon. Diabetes 45:725-730

Hayakawa, T.; Takamura, T.; Abe, T. \& Kaneko, S. (2007). Association of the C825T polymorphism of the G-protein $\beta 3$ subunit gene with hypertension, obesity, hyperlipidemia, insulin resistance, diabetes, diabetic complications, and diabetic therapies among Japanese. Metabolism 56:44-8

Haynes, WG.; Strachan, FE. \& Webb, DJ. (1995). Endothelin ETA and ETB receptors cause vasoconstriction of human resistance and capacitance vessels in vivo. Circulation 92:357-363

Hengstenberg, C.; Schunkert, H.; Mayer, B.; Doring, A.; Lowel, H.; Hense, HW.; Fischer, M.; Riegger, GA. \& Holmer, SR. (2001). Association between a polymorphism in the G protein beta3 subunit gene (GNB3) with arterial hypertension but not with myocardial infarction. Cardiovasc Res 49:820-7

Henskens, LH.; Spiering, W.; Stoffers, HE.; Soomers, FL.; Vlietinck, RF.; de Leeuw, PW. \& Kroon, AA. (2003). Effects of ACE I/D and AT1R-A1166C polymorphisms on blood pressure in a healthy normotensive primary care population: first results of the Hippocates study. J Hypertens 21:81-6

Hilgers, KF. \& Schmidt, BM. (2005). Gene variants of aldosterone synthase and hypertension. J Hypertens 23:1957-9

Hirata, Y.; Emori, T.; Eguchi, S.; Kanno, K.; Imai, T.; Ohta, K. \& Marumo, F. (1993). Endothelin receptor subtype B mediates synthesis of nitric oxide by cultured bovine endothelial cells. J Clin Invest 91:1367-1373

Hoehe, MR.; Otterud, B.; Hsieh, W-T.; Martinez, MM.; Stauffer, D.; Holik, J.; Berrettini, WH.; Byerley, WF.; Gershon, ES. \& Lalouel, JM. (1995). Genetic mapping of adrenergic receptor genes in humans. J Mol Med 73:299-306

Horio, T.; Kamide, K.; Takiuchi, S.; Yoshii, M.; Miwa, Y.; Matayoshi, T.; Yoshihara, F.; Nakamura, S.; Tokudome, T.; Miyata, T. \& Kawano, Y. (2010). Association of insulin-like growth factor-1 receptor gene polymorphisms with left ventricular mass and geometry in essential hypertension. J Hum Hypertens 24:320-6

Hyndman, MF.; Parsons, HG.; Verma, S.; Bridge, PJ.; Edworthy, S.; Jones, C.; Lonn, E.; Charbonneau, F. \& Anderson, TJ. (2002). The T-786 C mutation in endothelial nitric oxide synthase is associated with hypertension. Hypertension 39:919-922

Hyun-Seok, J.; Kyung-Won, H.; Ji-Eun, L.; Sue-Yun, H.; Sang-Ho, L.; Chol, S.; Hun Kuk, P. \& Bermseok, O. (2010). Genetic Variations in the Sodium Balance-Regulating Genes ENaC, NEDD4L, NDFIP2 and USP2 Influence Blood Pressure and Hypertension. Kidney Blood Press Res 33:15-23

Ishikawa, K.; Imai, Y.; Katsuya, T.; Ohkubo, T.; Tsuji, I.; Nagai, K.; Nakata, Y.; Satoh, H.; Hisamichi, S.; Higaki. J. \& Ogihara ,T. (2000). Human G-protein $\beta 3$ subunit variant is associated with serum potassium and total cholesterol levels but not with blood pressure. Am J Hypertens 13:140-5

Iwai, N.; Iwai, N.; Baba, S.; Mannami, T.; Ogihara, T. \& Ogata, J. (2002). Association of sodium channel alpha subunit promoter variant with blood pressure. J Am Soc Nephrol 13:80-85

Jachymova, M.; Horky, K.; Bultas, J.; Kozich, V.; Jindra, A.; Peleska, J. \& Martásek, P. (2001). Association of the Glu298Asp polymorphism in the endothelial nitric oxide 
synthase gene with essential hypertension resistant to conventional therapy. Biochem Biophys Res Commun 284:426-430

Jenny, NS.; Tracy, RP.; Ogg, MS.; Luongle, A.; Kuller, LH.; Arnold, AM.; Sharrett, AR. \& Humphries, SE. (2002). In the elderly, interleukin-6 plasma levels and the _174G>C polymorphism are associated with the development of cardiovascular disease. Arterioscler Thromb Vasc Biol 22:2066-71

Jeunemaitre, X. (2008). Genetics of the human renin angiotensin system. J Mol Med 86:637641.

Jeunemaitre, X.; Soubrier, F.; Kotelevtsev, YV. ; Lifton, RP.; Williams, CS.; Charru, A.; Hunt, SC.; Hopkins, PN.; Williams, RR. \& Lalouel, JM. (1992). Molecular basis of human hypertension: role of angiotensinogen. Cell 71:169-180

Jin, JJ.; Nakura, J.; Wu, Z.; Yamamoto, M.; Abe, M.; Chen, Y.; Tabara, Y.; Yamamoto, Y.; Igase, M.; Bo, X.; Kohara, K .\& Miki, T. (2003a). Association of angiotensin II type 2 receptor gene variant with hypertension. Hypertens res 26:547-52

Jin, JJ.; Nakura, J.; Wu, Z.; Yamamoto, M.; Abe, M.; Tabara, Y.; Yamamoto, Y.; Igase, M.; Kohara, K. \& Miki, T. (2003b). Association of endothelin-1 gene variant with hypertension. Hypertension 41:163-7

Ju, Z.; Zhang, H. ; Sun, K. ; Song, Y. ; Lu, H. ; Hui, R. \& Huang, X. (2003). Alpha-adducin gene polymorphism is associated with essential hypertension in Chinese: A casecontrol and family-based study. J Hypertens 21:1861-8

Juul, A.; Scheike, T.; Davidsen, M.; Gyllenborg, J. \& Jorgensen, T. (2002). Low serum insulinlike growth factor I is associated with increased risk of ischemic heart disease: a population-based case-control study. Circulation 106:939-944

Kainulainen, K.; Perola, M.; Terwilliger, J.; Kaprio, J.; Kaskenvuo, M.; Syvänen, AC.; Vartianen, I.; Peltonen, L. \& Kontula, K. (1999). Evidence for the involvement of the type 1 angiotensin II receptor locus in essential hypertension. Hypertension 33:844-9

Kamida, K.; Tanaka, C.; Takiuchi, S.; Miwa, Y.; Yoshii, M.; Horio, T.; Kawano, Y. \& Miyata, T. (2004). Six missense mutations of the epithelial sodium channel: $\beta$ and $\gamma$ subunits in Japanese Hypertensives. Hypertens Res 27:333-38

Kato, N.; Sugiyama, T.; Morital, H.; Morital, H.; Nabikas, T.; Kurihara, H.; Yamori, Y. \& Yazaki, Y. (2000). Genetic analysis of the atrial natriuretic peptide gene in essential hypertension. Clin Sci 98:251-8

Kauma, H.; Savolainen, MJ.; Rantala, AO. ; Lilja, M.; Kervinen, K.; Reunanen, A. \& Kesäniemi, YA. (1998). Apolipoprotein E phenotype determines the effect of alcohol on blood pressure in middle-aged men. Am J Hypertens 11:1334-43

Kazantsev, A.; Yamaoka, LH. \& Roses, AD. (1992). A dinucleotide repeat polymorphism in the human NaKATPase, alpha subunit (ATP1A3) gene. Nucleic Acids Res 20:1164

Knott, TJ.; Rall, SCJr.; Innerarity, TL.; Jacobson, SF.; Urdea, MS.; Levy-Wilson, B.; Powell, LM.; Pease, RJ.; Eddy, R.; Nakai, H.; Byers, M.; Priestley, LM.; Robertson, E.; Rall, LB.; Betsholtz, C.; Shows, TB.; Mahley, RW. \& Scott, J. (1985). Human apolipoprotein B: structure of carboxyl-terminal domains, sites of gene expression, and chromosomal localization. Science 230:37-43

Knott, TJ.; Wallis, SC.; Powell, LM.; Pease, RJ.; Lusis, AJ.; Blackhart, B.; McCarthy, BJ.; Wilson, B. \& Scott, J. (1986). A hypervariable region 3' to the human apolipoprotein B gene. Nucleic acids research 14:7501-7503 
Kosuge, K.; Soma, M.; Nakayama, T.; Aoi, N.; Sato, M.; Isumi, Y. \& Matsumoto, K. (2007). A novel variable number of tandem repeat of the natriuretic peptide precursor $B$ gene's $5^{\prime}$-flanking region is associated with essential hypertension among Japanese females. Int J Med Sci 4:146-152

Kotanko, P.; Binder, A.; Tasker, J.; DeFreitas, P.; Kamdar, S.; Clark, AJL.; Skrabal, F. \& Caulfield, M. (1997). Essential hypertension in African Caribbeans associates with a variant of the b-2 adrenoceptor. Hypertension 30:773-776

Kumar, NN.; Benjafield, AV.; Lin, RC.; Wang, WY.; Stowasser, M. \& Morris, BJ. (2003). Haplotype analysis of aldosterone synthase gene (CYP11B2) polymorphisms shows association with essential hypertension. J Hypertens 21:1331-7

Kunz, R.; Kreutz, R.; Beige, J.; Distler, A. \& Sharma, AM. (1997). Association between the angiotensinogen $235 \mathrm{~T}$ variant and essential hypertension in whites: a systematic review and methodological appraisal. Hypertension 30:1331-1337

Kuznetsova, T.; Citterio, L.; Herbots, L.; Carpini, SD.; Thijs, L.; Casamassima, N.; Richart, T.; Fagard, RH.; Bianchi, G. \& Staessen, JA. (2008). Effects of genetic variation in adducin on left ventricular diastolic function as assessed by tissue doppler imaging in a Flemish population. J Hypertens 26:1229-1236

Laburthe, M.; Couvineau, A.; Gaudin, P.; Maoret, JJ. ; Rouyer-Fessard, C. \& Nicole, P. (1996). Receptors for VIP, PACAP, secretin, GRF, glucagon, GLP-1, and other members of their new family of $G$ protein-linked receptors: structure-function relationship with special reference to the human VIP-1 receptor. Ann NY Acad Sci 805:94-109

Lajemi, M.; Labat, C.; Gautier, S.; Lacolley, P.; Safar, M.; Asmar, R.; Cambien, F.; \& Benetos, A. (2001). Angiotensin II type 1 receptor-153A/G and 1166A/C gene polymorphisms and increase in aortic stiffness with age in hypertensive subjects. $J$ Hypertens 19:407-13

Lalley, PA.; Francke, U. \& Minna, JD. (1978). Homologous genes for enolase, phosphogluconate dehydrogenase, phosphoglucomutase, and adenylate kinase are syntenic on mouse chromosome 4 and human chromosome 1p. Proc Natl Acad Sci USA 75:2382-2386

Lang, CC.; Stein, CM.; Brown, RM.; Deegan, R.; Nelson, R.; He, HB.; Wood, M. \& Wood, AJ. (1995). Attenuation of isoproterenol-mediated vasodilatation in blacks. $N$ Engl J Med 333:155-160

Lanzani, C.; Citterio, L.; Jankaricova, M.; Sciarrone, MT.; Barlassina, C.; Fattori, S.; Messaggio, E.; Serio, CD., Zagato,L.; Cusi, D.; Hamlyn, JM.; Stella, A., Bianchi, G. \& Manunta, P. (2005). Role of the adducin family genes in human essential hypertension. J Hypertens 23:543-549

Levin, ER. (1995). Endothelins. N Engl J Med 333:356-363

Lifton, RP.; Gharavi, AG. \& Geller, DS. (2001). Molecular mechanisms of human hypertension. Cell 104:545-556

Liu, A.; Lee, L.; Zhan, S.; Cao, W.; Lv, J.;Guo, X. \& Hu, Y. (2004). The S447X polymorphism of the lipoprotein lipase gene is associated with lipoprotein lipid and blood pressure levels in Chinese patients with essential hypertension. J Hypertens 22:1503-9

Lou, Y.; Liu, J.; Li, Y.; Liu, Y.; Wang, Z.; Liu, K.; Wu, H.; Niu, Q.; Gu, Y.; Guo, Y.; Li, Z. \& Wen, S. (2011). Association Study of the b2-Adrenergic Receptor Gene Polymorphisms and Hypertension in the Northern Han Chinese. In: PloS one, 
01.08.2011, Available from http: // www.plosone.org 6 April 2011 | Volume 6 | Issue 4 | e18590

MacGregor, AJ.; Snieder, H.; Schork, NJ. \& Spector, TD. (2000). Twins: novel uses to study complex traits and genetic diseases. Trends Genet 16:131-134

Mansego, ML.; Redon, J.; Marin, R.; Gonzalez-Albert, V.; Martin-Escudero, JC.; Fabia, MJ.; Martinez, F. \& Chaves, FJ. (2008). Renin polymorphisms and haplotypes are associated with blood pressure levels and hypertension risk in postmenopausal women. J Hypertens 26:230-23

Maqbool, A.; Hall, AS.; Ball, SG. \& Balmforth, AJ. (1999). Common polymorphisms of $\beta 1-$ adrenoceptor: identification and rapid screening assay. Lancet 353:897

Martin, MM. \& Elton, TS. (1995). The sequence and genomic organization of the human type 2 angiotensin II receptor. Biochem Bioph Res Commun 209:554-62

Masharani, U. \& Frossard, PM. (1988). MspI and HindIII restriction fragment length polymorphisms at the human Na,K-ATPase betasubunit (ATP1B) gene locus. Hum Genet 80:308

Matsubara, M.; Metoki, H.; Suzuki, M.; Fujiwara, T.; Kikuya, M.; Michimata, M.; Ohkubo, T.; Hozawa, A.; Tsuji, I.; Hisamichi, S.; Araki, T. \& Imai, Y. (2002). Genotypes of the betaENaC gene have little influence on blood pressure level in the Japanese population. Am J Hypertens 15:189-92

Matsubara, M.; Sato, T.; Nishimura, T.; Suzuki, M.; Kikuya, M.; Metoki, H.; Michimata, M.; Tsuji, I.; Ogihara, T. \& Imai, Y. (2004). CYP11B2 polymorphisms and home blood pressure in a population-based cohort in Japanese: the Ohasama study. Hypertens Res 27:1-6

Matsukawa, N.; Grzesik, WJ.; Takahashi, N.; Pandey, KN.; Pang, S.; Yamauchi, M. \& Smithies, O. (1999). The natriuretic peptide clearance receptor locally modulates the physiological effects of the natriuretic peptide system. Proc Natl Acad Sci 96:74037408

Matsuoka, Y.; Li, X. \& Bennett, V. (2000) Adducin: structure, function and regulation. Cell Mol Life Sci 57:884-895

Melander, O.; Ortho-Melander, M.; Bengtsson, K.; Lindblad, U.; Râstam, L.; Groop, L. \& Hulthén, UL. (2000). Genetic variants of thiazide-sensitive $\mathrm{NaCl}$-cotransporter in Gitlman's syndrome and primary hypertension. Hypertension 36:389-394

Men, C.; Tang, K.; Lin, G.; Li, J. \& Zhan, Y. (2001). ENOS-G894T polymorphism is a risk factor for essential hypertension in China. Indian J Biochem 48:154-7

Mercer, RW.; Schneider, JW.; Savitz, A.; Emanuel, J.; Benz, EJ Jr. \& Levenson, R. (1986). Ratbrain $\mathrm{Na}, \mathrm{K}-\mathrm{ATPase}$ beta-chain gene: primary structure, tissue-specific expression, and amplification in ouabain-resistant HeLa C+ cells. Mol Cell Biol 6:3884-3890

Mesrati, FH. (2007). Essential hypertension. Lancet 370:591-603

Michalkiewicz, M.; Zhao, GQ.; Jia, Z;. Michalkiewicz, T. \& Racadio, MJ. (2005). Central neuropeptide $\mathrm{Y}$ signaling ameliorates $\mathrm{N}$ (omega)-nitro-L-arginine methyl ester hypertension in the rat through a Y1 receptor mechanism. Hypertension 45:780-785

Mische, SM.; Mooseker, MS. \& Morrow, JS. (1987). Erythrocyte adducin : A calmodulinregulated actin-bundling protein that stimulates spectrin-actin binding. J Cell Biol 105:2837-2845

Moore, JD.; Mason, DA.; Green, SA.; Hsu, J. \& Liggett, SB. (1999). Racial differences in the frequencies of cardiac $\beta$ 1-adrenergic receptor polymorphisms: analysis of c145A3G and c1165G3C. Hum Mutat 14:271 
Morris, BJ.; Jeyasingam, CL.; Zhang, W.; Curtain, RP. \& Griffiths, LR. (1997). Influence of family history on frequency of glucagon receptor Gly40Ser mutation in hypertensive subjects. Hypertension 30:1640-1641

Nakajima, T.; Ota, N.; Yoshida, H.; Watanabe, S.; Suzuki, T. \& Emi, M. (1999). Allelic variants in the interleukin-6 gene and essential hypertension in Japanese women. Genes Immun 1:115-119

Nicod, J.; Bruhin, D.; Auer, L.; Vogt, B.; Frey, FJ. \& Ferrari, P. (2003). A biallelic gene polymorphism of CYP11B2 predicts increased aldosterone to renin ratio in selected hypertensive patients. J Clin Endocrinol Metab 88:2495-500

Nishimura, H.; Yerkes, E.; Hohenfellner, K.; Miyazaki, Y.; Ma, J.; Hunley, TE.; Yoshida, H.; Ichiki, T.; Threadgill, D.; Phillips, JA.; Hogan, BM.; Fogo, A.; Brock, JW.; Inagami, T.\& Ichikawa, I. (1999). Role of the angiotensin type 2 receptor gene in congenital anomalies of the kidney and urinary tract, CAKUT, of mice and men. Mol Cell 3:110

O'Shaughnessy, KM. (2001). The genetics of essential hypertension. Br J Clin Pharmacol 51:511

Obermüller, N.; Bernstein, P.; Velazquez, H.; Reilly, R.; Reilly, R.; Moser, D.; Ellison, DH. \& Bachmann, S. (1995). Expression of the thiazide-sensitive $\mathrm{Na}-\mathrm{Cl}$ cotransporter in rat and human Kidney. Am J Physiol 269:F900-F910

Ogawa, Y.; Itoh, H. \& Nakao, K. (1995). Molecular bioloby and biochemistry of natriuretic peptide family. Clin Exp Pharmacol Physiol 22:49-53

Oka, K;. Tkalcevic, GT.; Stocks, J.; Galton, DJ. \& Brown, WV. (1989). Nucleotide sequence of PvuII polymorphic site at the lipoprotein lipase gene locus. Nucleic Acids Res 17:6752

Ono, K.; Mannami, T.; Baba, S.; Tomoike, H.; Suga, S. \& Iwai, N. (2002). A Single-Nucleotide Polymorphism in C-Type Natriuretic Peptide Gene May Be Associated with Hypertension. Hypertens Res 25:727-730

Ormezzano, O.; Poirier, O.; Mallion, JM.; Nicaud, V.; Amar, J.; Chamontin, B.; MounierVéhier, C.; François, P. ; Cambien, F. \& Baguet, JP. (2005). A polymorphism in the endothelin-A receptor gene is linked to baroreflex sensitivity. J Hypertens 23:2019-26

Orzechowski, HD.; Richter, CM.; Funke-Kaiser, H.; Kroger, B.; Schmidt, M.; Menzel, S.; Bohnemeier, H. \& Paul, M. (1997). Evidence of alternative promoters directing isoform-specific expression of human endothelin-converting enzyme-1 mRNA in cultured endothelial cells. J Mol Med 75:512-521

Pankow, JS.; Rose, KM.; Oberman, A.; Hunt, SC.; Atwood, LD.; Djousse, L.; Province, MA. \& Rao, DC.; (2000). Possible locus on chromosome 18q influencing postural systolic blood pressure changes. Hypertension 36:471-476

Philippe, MF.; Enyioma, N.; Obineche, G. \& Lestringant, G. (1999). Association of an apolipoprotein B gene marker with essential hypertension. Hypertension 33:10521056

Plotkin, MD.; Kaplan, MR.; Verlander, JW.; Lee, WS.; Xu, ZC.; Lytton, J. \& Hebert, SC. (1996). Localization of the thiazide sensitive Na-Cl cotransporter, rTSC1 in the rat kidney. Kidney Int. 50:174-183

Poirier, O.; Georges, JL.; Ricard, S.; Arveiler, D.; Ruidavets, JB.; Luc, G.; Evans, A.; Cambien, F. \& Tiret, L. (1998). New polymorphisms of the angiotensin II type 1 receptor gene 
and their associations with myocardial infarction and blood pressure: the ECTIM study. Etude Cas-Témoin de l'Infarctus du Myocarde (1988). J Hypertens 16:1443-7

Pola, R.; Flex, A.; Gaetani, E.; Pola, P. \& Bernabei, R. (2002). The -174 G/C polymorphism of the interleukin-6 gene promoter and essential hypertension in an elderly Italian population. J Hum Hypertens 16:637-640

Rahman, T.; Baker, M.; Hall, DH.; Avery, PJ. \& Keavney, B. (2008). Common genetic variation in the type A endothelin-1 receptor is associated with ambulatory blood pressure: a family study. J Hum Hypertens 22:282-8

Rauramaa, R.; Väisänen, SB.; Luong, LA.; Schmidt-Trücksäss, A.; Penttilä, IM.; Bouchard, C.; Töyry, J. \& Humphries, SE. (2000). Stromelysin-1 and interleukin-6 gene promoter polymorphisms are determinants of asymptomatic carotid artery atherosclerosis. Arterioscler Thromb Vasc Biol 20:2657-2662

Ridker, PM.; Rifai, N.; Stampfer, MJ. \& Hennekens, CH; (2000). Plasma concentration of interleukin- 6 and the risk of future myocardial infarction among apparently healthy men. Circulation 101:1767-72

Rigat, B.; Hubert, C.; Alhenc-Gelas, F. ; Cambien, F. ; Corvol, P. \& Soubrier, F. (1990). An insertion/deletion polymorphism in the angiotensin I converting enzyme gene accounting for half the variance of serum enzyme levels. J Clin Invest 86:1343-6

Rubattu, S.; Bigatti, G.; Evangelista, A.; Lanzani, C.; Stanzione, R.; Zagato, L.; Manunta, P.; Marchitti, S.; Venturelli, V.; Bianchi, G.; Volpe, M. \& Stella, P. (2006). Association of atrial natriuretic peptide and type a natriuretic peptide receptor gene polymorphisms with left ventricular mass in human essential hypertension. J Am Coll Cardiol 48: 499-505

Rubattu, S. \& Volpe, M. (2001). The atrial natriuretic peptide: a changing view. J Hypertens 19:1923-31

Russo, CJ.; Melista, E.; Cui, J.; De Stefano, AL.; Bakris, GL.; Manolis, AJ.; Gavras, H. \& Baldwin, CT. (2005). Association of NEDD4L Ubiquitin Ligase with Essential Hypertension. Hypertension 46:488-491

Rutledge, DR.; Sun, Y. \& Ross, EA. (1995). Polymorphisms within the atrial natriuretic peptide gene in essential hypertension. J Hypertens 13:953-5

Sacks, FM.; Alaupovic, P.; Moye, LA. ; Cole, TG. ; Sussex, B.; Stampfer, MJ.; Pfeffer, MA. \& Braunwald, E. (2000). VLDL, apolipoproteins B, CIII, and E, and risk of recurrent coronary events in the Cholesterol and Recurrent Events (CARE) trial. Circulation 102:1886-1892

Salah, A.; Khan, M.; Esmail, N.; Habibullah, S. \& Al Lahham, Y. (2009). Genetic polymorphism of S447X lipoprotein lipase (LPL) and the susceptibility to hypertension. J Crit Care 24:e11-4

Schmieder, RE.; Martus, P. \& Klingbeit, A. (1996). Reversal of left ventricular hypertrophy in essential hypertension. A meta-analysis of randomized double blind studies. JAMA 275:1507-13

Schunkert, H.; Hense, HW.; Doring, A.; Riegger, GA; \& Siffert, W. (1998). Association between a polymorphism in the $G$ protein $\beta 3$ subunit gene and lower renin and elevated diastolic blood pressure levels. Hypertension 32:510-3

Schweizer, A.; Valdenaire, O.; Nelbock, P.; Deuschle, U.; Dumas, Milne Edwards, JB.; Stumpf, JG. \& Loffler, BM. (1997) Human ECE-1: three isoforms with distinct subcellular localizations. Biochem J 328:871-877 
Sethi, AA.; Nordestgaard, BG.; Tybjaerg-Hansen, A. \& Tybjaerg-Hansen, A. (2003). Angiotensinogen gene polymorphism, plasma angiotensinogen, and risk of hypertension and ischemic heart disease: a meta-analysis. Arterioscler Thromb Vasc Biol 23:1269-1275

Sharma, P.; Hingorani, A;. Jia, H.; Hopper, R. \& Brown, MJ. (1999). Quantitative association between a newly identified molecular variant in the endothelin-2 gene and human essential hypertension. J Hypertens 17:1281-7

Shimada, K.; Matsushita, Y.; Wakabayashi, K.; Takahashi, M.; Matsubara, A.; Iijima, Y. \& Tanzawa, K. (1995) Cloning and functional expression of human endothelinconverting enzyme cDNA. Biochem Biophys Res Commun 207:807-12

Shoji, M.; Tsutaya, S.; Saito, R,.; Takamatu, H. \& Yasujima, M. (2000). Positive association of endothelial nitric oxide synthase gene polymorphism with hypertension in northern Japan. Life Sci 66:2557-2562

Shull, M.M. \& Lingrel, JB. (1987). Multiple genes encode the human Na+,K+-ATPase catalytic subunit (multiple isoforms/genomic library). Proc Nat Acad Sci USA 84:4039-4043

Shull, MM.; Pugh, DG. \& Lingrel, J. (1990). The human Na,K-ATPase alpha 1 gene characterization of the 5 -flanking region and identification of a restriction fragment length polymorphism. Genomics 6:451-60

Siffert, W. (2003). G protein beta 3 subunit $825 \mathrm{~T}$ allele and hypertension. Curr Hypertens res 5:47-53

Siffert, W.; Forster, P.; Jockel, KH.; Mvere, DA.; Brinkmann, B.; Naber, C,.; Crookes, R,.; Du, P.; Heyns, A.; Epplen, JT.; Fridey, J.; Freedman, BI.; Müller, N.; Stolke, D.; Sharma, AM.; Al Moutaery, K.; Grosse-Wilde, H.; Buerbaum, B.; Ehrlich, T.; Ahmad, HR.; Horsthemke, B.; Du Toit, ED.; Tiilikainen, A.; Ge, J. \& Wang, Y. (1999). Worldwide ethnic distribution of the $G$ protein $\beta 3$ subunit $825 \mathrm{~T}$ allele and its association with obesity in Caucasian, Chinese, and black African individuals. J Am Soc Nephrol 10:1921-31

Siffert, W.; Rosskopf, D.; Siffert, G.; Busch, S.; Moritz, A.; Erbel, R.; Sharma, AM.; Ritz, E,.; Wichmann, HE.; Jakobs, KH. \& Horsthemke, B. (1998). Association of a human G protein $\beta 3$ subunit variant with hypertension. Nat Genet 18:45-8

Siffert, WG. (1996) proteins, hypertension, and coronary heart disease: novel findings and hypotheses. Kidney Blood Press Res 19:71-80

Simon, DB.; Nelson-Williams, C.; Bia, MJ.; Ellison, D.; Karet, FE.; Molina, AM.; Vaara, I.; Iwata, F.; Cushner, HM.; Koolen, M.; Gainza, FJ.; Gitleman, HJ. \& Lifton, RP. (1996). Gitelman's variant of Bartter's syndrome, inherited hypokalaemic alkalosis, is caused by mutations in the thiazide-sensitive $\mathrm{Na}-\mathrm{Cl}$ cotransporter. Nat Genet 12:24-30

Sparkes, RS.; Zollman, S.; Klisak, I.; Kirchgessner, TG.; Komaromy, MC.; Mohandas, T.; Schotz, MC. \& Lusis, AJ. (1987). Human genes involved in lipolysis of plasma lipoproteins: mapping of loci for lipoprotein lipase to 8 p22 and hepatic lipase to 15q21. Genomics 1:138-144

Strader, CD.; Fong, TM.; Tota, MR.; Underwood, D. \& Dixon, RA. (1994). Structure and function of G protein-coupled receptors. Annu Rev Biochem 463:101-132

Sun, B.; Williams, JS.; Pojoga, L.; Chamarthi, B.; Lasky-Su, J.; Raby, BA.; Hopkins, PN.; Jeunemaitre, x.; Brown, NJ,.; Ferri, C. \& Williams, GH. (2011). Renin gene 
polymorphism: its relationship to hypertension, renin levels and vascular responses. J Renin Angiotensin Aldosterone Syst April 13. [Epub ahead of print]

Svetkey, LP.; Chen, YT.; McKeown, SP.; Preis, L. \& Wilson, AF. (1997). Preliminary evidence of linkage of salt sensitivity in black Americans at the beta-2 adrenergic receptor locus. Hypertension 29:918-922

Sweadner, KJ. (1989). Isozymes of the Na/KATPase. Biochim Biophys Acta 988:185-220

Takahashi, N.; Murakami, H.; Kodama, K.; Kasagi, F.; Yamada, M.; Nishishita, T. \& Inagami, T. (2000). Association of a polymorphism at the 5'-region of the angiotensin II type 1 receptor with hypertension Ann Hum Genet 64:197-205

Takiyyuddin, MA.; Brown, MR.; Dinh, TQ.; Cervenka, JH.; Braun, SD.; Parmer, RJ.; Kennedy, B. \& O'Connor, DT. (1994). Sympatho-adrenal secretion in humans: factors governing catecholamine and storage vesicle peptide co-release. J Auton Pharmacol 14:187-200

Taupenot, L.; Harper, KL. \& O'Connor, DT. (2003). The chromogranin-secretogranin family. N Engl J Med 348:1134-1149

Tikhonoff, V.; Kuznetsova, T.; Stolarz, K.; Bianchi, G.; Casiglia, E.; Kawecka-Jaszcz, K.; Nikitin, Y.; Tizzoni, L.; Wang, JG. \& Staessen, JA. (2003). $\beta$-Adducin polymorphisms, blood pressure and sodium excretion in three European populations. Am J Hypertens 16:840-846

Timberlake, DS.; O'Connor, DT. \& Parmer, RJ. (2001). Molecular genetics of essential hypertension: Recent results and emerging strateries. Curr Opin Nephrol Hypertens 10:71-79

Timmermann, B.; Rune, M.; Luft, FC.; Gerdts, B.; Busjahn, A.; Omvik, P.; Guo-Hua, L.; Schuster, H.; Wienker, TF.; Hoehe , M. \& Lund-Johansen, P. (1998). $\beta-2$ adrenoceptor genetic variation is associated with genetic predisposition to essential hypertension: the Bergen Blood Pressure Study. Kidney Int 53:1455-1460

Tomaszewski, M.; Charchar, FJ.; Lacka, B.; Pesonen, U., William Y.S. Wang, WYS.; Zukowska-Szczechowska, E.; Grzeszczak, W. \& Dominiczak AF. (2004). Epistatic interaction between _2-adrenergic receptor and neuropeptide $\mathrm{Y}$ genes influences LDL-cholesterol in hypertension. Hypertension 44:689-694

Tonolo, G.; Melis, MG.; Ciccarese, M.; Secchi, G.; Atzeni, MM.; Maioli, M.; Pala, G.; Massidda, A.; Manai, M.; Pilosu, RM.; Li, LS. \& Luthman, H. (1997). Physiological and genetic characterization of the Gly40Ser mutation in the glucagon receptor gene in the Sardinian population: the Sardinian. Diabetes genetic study group. Diabetologia 40:89-94

Tripodi, G.; Valtorta, F.; Torielli, L.; Chieregatti, E.; Salardi, S. ; Trusolino, L. ; Menegon, A. ; Ferrari, P. ; Marchisio, PC. \& Bianchi, G. (1996). Hypertension associated point mutations in the adducin alpha and beta subunits affect actin cytoskeleton and ion transport. J Clin Invest 97:2815-2822

Tsai, CT.; Fallin, D.; Chiang, FT. ; Hwang, JJ. ; Lai, LP.; Hsu, KL. ; Tseng, CD. ; Liau, CS. \& Tseng YZ. (2003). Angiotensinogen gene haplotype and hypertension: interaction with ACE gene I allele. Hypertension 4:9-15

Turner, ST.; Chapman, AB.; Schwartz, GL. \& Boerwinkle, E. (2003). Effects of endothelial nitric oxide synthase, alpha-adducin, and other candidate gene polymorphisms on blood pressure response to hydrochlorothiazide. Am J Hypertens 16:834-839 
Uwabo, J.; Soma, M.; Nakayama, T. \& Kanmatsuse, K. (1998). Association of a variable number of tandem repeats in the endothelial constitutive nitric oxide synthase gene with essential hypertension in Japanese, Am J Hypertens 11:125-128

Vague, P.; Dufayet, D.; Coste, T.; Moriscot, C.; Jannot, MF. \& Raccah, D. (1997). Association of diabetic neuropathy with $\mathrm{Na} / \mathrm{K}$ ATPase gene polymorphism. Bull Acad Natl Med 181:1811-21

Valdenaire, O.; Lepailleur-Enouf, D.; Egidy, G.; Thouard, A.; Barret, A. ; Vranckx, R. ; Tougard, C. \& Michel, JB. (1999). A fourth isoform of endothelin-converting enzyme (ECE-1) is generated from an additional promoter. Eur J Biochem 264:341349

Valdenaire, O.; Rohrbacher, E. \& Mattei, MG. (1995). Organization of the gene encoding the human endothelin-converting enzyme (ECE-1). J Biol Chem 270:29794-29798

Vangjeli, C.; Clarke, N.; Quinn, U.; Dicker, P.; Tighe, O.; Ho, C.; O'Brien, E. \& Stanton, AV. (2010). Confirmation That the Renin Gene Distal Enhancer Polymorphism REN5312C/T Is Associated With Increased Blood Pressure. Circ Cardiovasc Genet 3: 5359

Vasků, A.; Soucek, M.; Znoji, 1 V.; Rihácek, I.; Tschöplová, S.; Strelcová, L.; Cídl, K.; Blazková, M.; Hájek, D.; Hollá, L. \& Vácha, J. (1998). Angiotensin I-converting enzyme and angiotensinogen gene interaction and prediction of essential hypertension. kidney Int 53:1479-82

Wallerstedt, SM.; Skrtic, S.; Eriksson, AL.; Ohlsson, C. \& Hedner, T. (2004). Association analysis of the polymorphism T1128C in the signal peptide of neuropeptide $\mathrm{Y}$ in a Swedish hypertensive population. J Hypertens 22(7):1277-81

Wang, JG. \& Staessen, JA. (2000). Genetic polymorphisms in the renin-angiotensin system: relevance for susceptibility to cardiovascular disease. Eur J Pharmacol 410:289-302

Wang, JG.; Staessen, JA. Barlassina, C.; Fagard, R.; Kuznetsova, T.; Struijker-Boudier, HA.; Zagato, L.; Citterio, L.; Messaggio, E. \& Bianchi, G. (2002). Association between hypertension and variation in the $\mathbf{x}$ - and $\boldsymbol{\beta}$-adducin genes in a white population. Kidney Int 62:2152-2159

Wang, L.; Rao, F.; Zhang, K.; Mahata M.; Rodriguez-Flores, JL.; Fung, MM.; Waalen, J.; Cockburn, MG.; Hamilton, BA.; Mahata, SK. \& O'Connor, DT. (2009). Neuropeptide Y1 receptor NPY1R: Discovery of naturally occurring human genetic variants governing gene expression in cella as well as pleiotropic effects on autonomic activity and blood pressure in vivo. J Am Coll Cardiol 54:944-954

Wang, WY.; Zee, RYL. \& Morris, BJ. (1997). Association of angiotensin II type I receptor gene polymorphism with essential hypertension. Clin Genet 51:31-4

Warnecke, C.; Willich, T.; Holzmeister, J.; Bottari, SP.; Fleck, E. \& Regitz-Zagrosek, V. (1999). Efficient transcription of the human angiotensin II type 2 receptor gene requires intronic sequence elements. Biochem J 340:17-24

Wen, H.; Lin, R.; Jiao, Y.; Wang, F.; Wang, S.; Lu, D.; Qian, J.; Jin, L. \& Wang, X. (2008). Two polymorphisms in NEDD4L gene and essential hypertension in Chinese Hans - a population-based case-control study. Clin Exp Hypertens 30:87-94

White, PC. \& Rainey, WE. (2003). Polymorphisms in CYP11B genes and 11-hydroxylase activity. J Clin Endocrinol Metab 90:1252-5

Williams, SM.; Addy, JH.; Phillips, JAIII.; Dai,DM.; Kpodonu J, Afful, J.; Jackson, H.; Joseph, K.; Eason, F.; Murray, MM.; Epperson, P.; Aduonum, A.; Wong, LJ.; Jose, PA.; \& 
Felder RA.(2000). Combinations of variations in multiple genes are associated with hypertension. Hypertension 36:2-6

Williams, SM.; Ritchie, MD.; Phillips, JAIII.; Dawson, E.; Prince, M.; Dzhura, E.; Willis, A.; Semenya, A.; Summar, M.; White, BC.; Addy JH.; Kpodonu J.; Wong LJ.; Felder RA.; Jose PA. \& Moore JH. (2004). Multilocus analysis of hypertension: a hierarchical approach. Hum Hered 57:28-38

Windler, E. \& Havel, RJ. (1985). Inhibitory effects of C apolipoproteins from rats and humans on the uptake of triglyceride-rich lipoproteins and their remnants by the perfused rat liver. J Lipid Res 26:556-65

Wong, ZY.; Stebbing, M.; Ellis, JA.; Lamantia, A. \& Harrap, SB. (1999). Genetic linkage of beta and gamma subunits of epithelial sodium channel to systolic blood pressure. Lancet 353:1222-1225

Xu, D. \& Yanagisawa, M. (1994) ECE-1: a membrane-bound metalloprotease that catalyzes the proteolytic activation of big endothelin-1. Cell 78:473-485

Yanagisawa, M.; Kurihara, H.; Kimura, S.; Tomobe, Y.; Kobayashi, M.; Mitsui, Y.; Yazaki, Y.; Goto, K. \& Masaki, T. (1988). A novel potent vasoconstrictor peptide produced by vascular endothelial cells. Nature 332:411-415

Yang, W.; Huang, J.; Ge, D.; Yao, C.; Duan, X.; Gan, W.; Huang, G.; Zhao, J.; Hui, R.; Shen, Y.; Qiang, B. \& Gu, D. (2003). Variation near the region of the lipoprotein lipase gene and hypertension or blood pressure levels in Chinese. Hypertens Res 26:459-64

Ying, CQ.; Wang, YH.; Wu, ZL.; Fang, MW.; Wang, J.; Li, YS.; Zhang, YH. \& Qiu, CC. (2010). Association of the renin gene polymorphism, three angiotensinogen polymorphism and the haplotypes with essentiel hypertension in the Mongolian population. Clin Exp Hypertens 32:293-300

Zhang, Y.; Zhang, KX.; Wang, GL.; Huang, W. \& Zhu, DL. (2003). Angiotensin II type 2 receptor gene polymorphisms and essential hypertension. Acta Pharmacol Sin 24:1089-93

Zhao, Q.; Gu D.; Hixson, JE.; Liu, DP.; Rao, DC.; Jaquish, CE. ; Kelly, TN.; Lu, F.; Ma, J.; Mu, J.; Shimmin, LC.; Chedn, J.; Mei, H.; Hamm, LL. \& He, J. (2011). Common variants in epithelial sodium channel genes contribute to salt-sensitivity of blood pressure: the GenSalt study. Circ Cardiovasc Genet (Epub ahead of print)

Zhu, X.; Chang, YP.; Yan, D.; Weder, A.; Cooper, R.; Luke, A.; Kan, D. \& Chakravarti, A. (2003). Associations between hypertension and genes in the renin-angiotensin system. Hypertension 41:1027-1034

Zintzaras, E.; Kitsios, G. \& Stefanidis, I. (2006). Endothelial NO synthase gene polymorphisms and hypertension: a meta-analysis. Hypertension 48:700-710

Zivković, M.; Djurić, T.; Stancić, O.; Alavantić, D. \& Stanković, A. (2007). Xlinked angiotensin II type 2 receptor gene polymorphism-1332A/G in male patients with essential hypertension. Clin Chim Acta 386:110-3

Zuliani, G. \& Hobbs, HH. (1990). Tetranucleotide repeat polymorphism in the LPL gene. Nucleic Acids Res 18:4958 


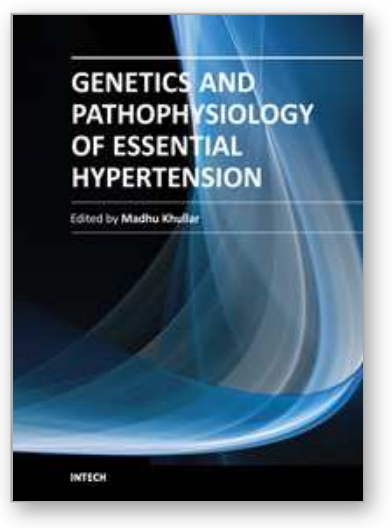

\author{
Genetics and Pathophysiology of Essential Hypertension \\ Edited by Prof. Madhu Khullar
}

ISBN 978-953-51-0282-3

Hard cover, 236 pages

Publisher InTech

Published online 09, March, 2012

Published in print edition March, 2012

This book, authored by renowned researchers in the field of Hypertension Research, details the state of the art knowledge in genetics, genomics and pathophysiology of Essential hypertension, specifically the genetic determinants of hypertension and role of gene variants in response to anti-hypertensive therapy. Two chapters describe mitochondrial mutations in Essential hypertension and in hypertension associated Left ventricular hypertrophy, one chapter reviews in detail the global gene expression in hypertension, and an up to date treatise on pathophysiology of resistant hypertension is detailed in another chapter. Other topics included in the book are end organ damage, baroreceptor sensitivity and role of music therapy in essential hypertension.

\title{
How to reference
}

In order to correctly reference this scholarly work, feel free to copy and paste the following:

Hayet Soualmia (2012). Candidate Genes in Hypertension, Genetics and Pathophysiology of Essential Hypertension, Prof. Madhu Khullar (Ed.), ISBN: 978-953-51-0282-3, InTech, Available from: http://www.intechopen.com/books/genetics-and-pathophysiology-of-essential-hypertension/genetic-variants-inessential-hypertension

\section{INTECH}

open science | open minds

\section{InTech Europe}

University Campus STeP Ri

Slavka Krautzeka 83/A

51000 Rijeka, Croatia

Phone: +385 (51) 770447

Fax: +385 (51) 686166

www.intechopen.com

\section{InTech China}

Unit 405, Office Block, Hotel Equatorial Shanghai

No.65, Yan An Road (West), Shanghai, 200040, China

中国上海市延安西路65号上海国际贵都大饭店办公楼 405 单元

Phone: +86-21-62489820

Fax: +86-21-62489821 
(C) 2012 The Author(s). Licensee IntechOpen. This is an open access article distributed under the terms of the Creative Commons Attribution 3.0 License, which permits unrestricted use, distribution, and reproduction in any medium, provided the original work is properly cited. 